\title{
Influence of Indian summer monsoon variability on the surface waves in the coastal regions of eastern Arabian Sea
}

\author{
V. Sanil Kumar and Jesbin George \\ Ocean Engineering Division, CSIR - National Institute of Oceanography, Dona Paula 403004, Goa, India \\ Correspondence to: Sanil Kumar (sanil@nio.org)
}

Received: 9 May 2016 - Revised: 27 September 2016 - Accepted: 27 September 2016 - Published: 18 October 2016

\begin{abstract}
We assess the influence of monsoon variability on the surface waves using measured wave data covering 7 years and reanalysis data from 1979 to 2015 during the Indian summer monsoon (JJAS) in the eastern Arabian Sea. The interannual comparison shows that the percentage of higher wave heights $(>2.5 \mathrm{~m})$ is higher $(\sim 26 \%)$ in 2014 than in other years due to the higher monsoon wind speed (average speed $\sim 7.3 \mathrm{~m} \mathrm{~s}^{-1}$ ) in 2014. Due to the delayed monsoon, monthly average significant wave height $\left(H_{\mathrm{m} 0}\right)$ of June was lowest $(\sim 1.5 \mathrm{~m})$ in 2009 . The spectral peak shifted to lower frequencies in September due to the reduction of wind seas as a result of decrease in monsoon intensity. The study shows high positive correlation $(r \sim 0.84)$ between average lowlevel jet (LLJ) for the block $0-15^{\circ} \mathrm{N}, 50-75^{\circ} \mathrm{E}$ and $H_{\mathrm{m} 0}$ of eastern Arabian Sea in all the months except in August $(r \sim 0.66)$. The time series data on wave height shows oscillations with periods 5 to 20 days. Wavelet coherence analysis indicates that the LLJ and $H_{\mathrm{m} 0}$ are in-phase related (phase angle $0^{\circ}$ ) almost all the time and LLJ leads $H_{\mathrm{m} 0}$. The monsoon seasonal anomaly of $H_{\mathrm{m} 0}$ is found to have a negative relationship with the Oceanic Niño Index indicating that the monsoon average $H_{\mathrm{m} 0}$ is relatively low during the strong El Niño years.
\end{abstract}

Keywords. History of geophysics (ocean sciences) - meteorology and atmospheric dynamics (waves and tides)

\section{Introduction}

The monsoons of the Indian Ocean are a result of strong atmosphere-ocean interaction over basin scales (Riser et al., 2008). In modulation of the monsoon over the north Indian Ocean, the Arabian Sea (AS) plays a vital role (Nayak, 2013). Despite having been studied for many decades, the inter-annual variability of the Indian summer monsoon (ISM) remains poorly understood and predicted (Walker et al., 2015). In some studies, the year-to-year variability of ISM is linked to variations in sea surface temperature (SST), particularly the large-scale climate variability in the tropics: El Niño-Southern Oscillation (ENSO) and Indian Ocean Dipole (IOD) (Sikka, 1980; Webster et al., 1998; Cherchi and Navarra, 2013). Reason et al. (2000) observed that during the summer when an El Niño occurred, weaker winds are observed than the normal in the Indian Ocean due to weakening of the westerly winds over the Indian Ocean. In the last two decades, the IOD (Saji et al., 1999) has been identified as a potential trigger of the ENSO-monsoon connection (Cherchi and Navarra, 2013). Fluctuations in multi-decadal scale are also present in the ISM rainfall forced mainly by the tropical SSTs (Cherchi and Navarra, 2013).

During the ISM, the beaches of west coast of India experience erosion and the erosion is severe in some years. The wind-generated waves (referred to as "waves" hereafter) at the sea surface play an important role in the erosion of the beaches (Chandramohan et al., 1994), and the variations in wave climate can be assessed based on analysis of long-term trends and climate variability (Sasaki et al., 2005). Changes in the wave climate are related to changes in the local or remote wind forcing. The changes that we observe in the waves of eastern AS during the ISM are studied extensively (Sanil Kumar et al., 2003, 2012, 2014; Chempalayil et al., 2012; Glejin et al., 2013; Amrutha et al., 2015). The inter-annual and inter-decadal variability in the significant wave heights of the north Indian Ocean during 1979 to 2012 is studied (Anoop et al., 2015). Anoop et al. (2015) studied the trend in significant wave height $\left(H_{\mathrm{m} 0}\right)$ during the ISM from 1979 to 2012 and reported that the $H_{\mathrm{m} 0}$ shows an increasing trend $\left(1 \mathrm{~cm} \mathrm{yr}^{-1}\right)$ in the northern AS. Although $H_{\mathrm{m} 0}$ is the most 
common parameter used to describe the wave climate variability, wave spectrum provides significantly more information, making it possible to differentiate between distant and local wave generation areas (Espejo et al., 2014). Variability in wave climate to the large-scale atmospheric circulation patterns, referred to as teleconnection patterns (e.g. ENSO) are studied (Hemer et al., 2010; Stopa and Cheung, 2014; Anoop et al., 2016). The variability of wave heights in the North Atlantic are linked to the North Atlantic Oscillation (NAO) (Izaguirre et al., 2011). Higher waves are reported in the eastern North Pacific during major El Niño events (Allan and Komar, 2000). Izaguirre et al. (2011) studied the extreme wave height variability on the global scale including the Indian Ocean sector using 10 global climatic indices and reported that the Antarctic Oscillation (AO), Southern Annular Mode (SAM), and ENSO are the most influential climate patterns influencing the inter-annual variability of extreme wave heights around the globe. The Madden-Julian Oscillation (MJO) is the dominant component of the intraseasonal (30-90 days) variability in the tropical atmosphere (Zhang, 2005). Marshall et al. (2015) observed that the MJO also influences the occurrence of daily low (below the 5th percentile) and high (above the 95th percentile) wave conditions across the tropics and in the North Pacific and North Atlantic, emphasizing that the MJO may be a valuable source of intraseasonal predictability of surface wave variability.

The ISM mean rainfall is approximately $8 \mathrm{~mm} \mathrm{day}^{-1}$, but the ISM is not a continual downpour during the entire summer, and it occurs as intra-seasonal pulses, referred to as active and break periods (Goswami, 2005). The cause of the monsoon breaks is still under active research (Rajeevan et al., 2010). One of the feature of the ISM is the low-level jet (LLJ) around $850 \mathrm{mb}$, originating in the southern Indian Ocean near Madagascar and emerges in the AS and flows across the central parts to west coast of India. The existence of a westerly LLJ over peninsular India with a strong vertical and horizontal shear was established by Joseph and Raman (1966). According to them, these LLJs are observed during June-August, but they are strongest during the month of July in the southern part of India. Later Findlater (1969) suggested a strong link with LLJ and ISM and suggested that LLJ originates in the Southern Hemisphere as easterlies and crosses the Equator as a southerly current through a narrow longitudinal belt near the eastern African coast and turns into westerlies and accounts for more than half of the inter-hemispheric transport of air. Joseph and Sijikumar (2004) also suggested the existence of a strong crossequatorial LLJ, with a core around $850 \mathrm{hPa}$ playing a vital role in ISM by transporting the moisture from the surrounding oceans to the Indian landmasses. Sandeep and Ajayamohan (2015) observed that enhanced warming to the north of western Indian Ocean in recent decades has led to a shift of the core of LLJ to the north. The studies based on the Coupled Model Intercomparison Project Phase 5 indicate a weakening of the large-scale ISM circulation in the middle

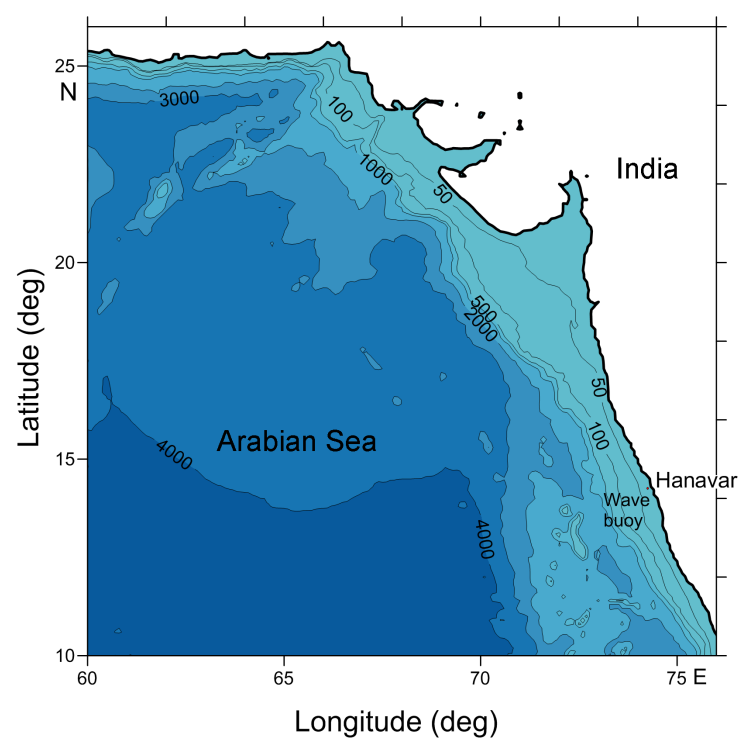

Figure 1. Map showing the buoy location off Honavar in the eastern Arabian Sea. The depth contours are in metres.

to upper atmosphere (Sooraj et al., 2014). Thus the location and strength of LLJ play an important role on the strength of ISM.

The fluctuations in the ISM wind pattern are expected to have an influence on the waves. There have been a number of studies on the factors controlling the intra-seasonal and interannual variability of the ISM (Goswami and Mohan, 2001). In contrast, to the best of our knowledge, there are almost no studies on the influence of LLJ on nearshore waves of AS and on the change in wave pattern due to the fluctuations in the ISM wind pattern. The objective of this paper is to analyse the influence of ISM on nearshore waves. We specifically would like to know how the wave characteristics vary during the ISM and what the influence of LLJ is on $H_{\mathrm{m} 0}$ in different years. The rest of the article is arranged as follows. Section 2 covers the details of study region and the data along with the methodology. Section 3 presents the results and discussions, and Sect. 4 contains the conclusions.

\section{Methods}

\subsection{Study area}

The location selected for the study is off Honavar at $2.5 \mathrm{~km}$ from the Indian mainland and is in the eastern AS (Fig. 1). The geographical co-ordinate of the measurement location is $14.3042^{\circ} \mathrm{N}, 74.3907^{\circ} \mathrm{E}$ and is at $9 \mathrm{~m}$ water depth. The average $H_{\mathrm{m} 0}$ in the eastern AS during the ISM is around $2.5 \mathrm{~m}$ and is $1.2 \mathrm{~m}$ during the rest of the period. The annual average value is $\sim 1.5 \mathrm{~m}$ (Anoop et al., 2015). During the non-monsoon period, the land and sea breeze has a significant influence on the wave climate of eastern AS (Glejin 
et al., 2013; Sanil Kumar and Anjali Nair, 2015; Amrutha et al., 2016). Long-period swells from the Southern Hemisphere were also observed in the eastern AS during the nonmonsoon season (Glejin et al., 2013). The swells from Southern Hemisphere are persistent throughout the year, while its information might be masked by bigger wind waves, so longperiod swell may not reflect in the bulk parameters during monsoon. The seasonal and annual variations in the bulk wave parameters of the study area within short timescale (from 2008 to 2011) were reported by Sajiv et al. (2012), who observed that the annual average $H_{\mathrm{m} 0}$ was almost same $(\sim 1 \mathrm{~m})$ during the 3 years. The wave spectral characteristics at this location during 2011 were studied by Sanil Kumar et al. (2014), who reported that $63 \%$ of the wave spectra were predominantly single peaked. Glejin et al. (2012) studied the spatial variation in wave characteristics along the central west coast of India during June to August 2010 and found an increase in the wave height from south to north. The interannual variations in wave spectra at Honavar from 2009 to 2012 were examined by Sanil Kumar and Anjali Nair (2015) and observed that the seasonal average wave spectrum during the ISM was single peaked and were double peaked during rest of the period. Anoop et al. (2016) reported about an intrinsic mode of variability that has a significant role in driving climate oscillations in the ocean and demonstrated the influence of the climate variability - IOD on the waves in the eastern AS during October.

\subsection{Data and methodology}

In this study, the measured wave data obtained from the moored directional waverider buoy (Datawell B.V., 2009) at a nearshore location were utilized. From the continuously recorded time series data at $1.28 \mathrm{~Hz}$, the data for $0.5 \mathrm{~h}$ duration were taken as one record. The wave data analysis procedure is similar to that presented in Sanil Kumar et al. (2013, 2014). The time referred to in the paper is in coordinated universal time (UTC). Significant wave height $\left(H_{\mathrm{m} 0}\right)$, spectral peak period $\left(T_{\mathrm{p}}\right)$, mean wave period $\left(T_{\mathrm{m} 02}\right)$ and maximum spectral energy density $\left(E_{\max }\right)$ were obtained from the wave spectrum (Datawell B.V., 2009). Mean wave direction $\left(D_{\mathrm{m}}\right)$ was estimated following Kuik et al. (1988). Directional spreading was studied using directional width $(\sigma)$ (Kuik et al., 1988). The directional wave spectrum was obtained through the maximum entropy method (MEM). The swells and the wind seas were separated from the measured data through a 1-D separation algorithm based on the assumption that the energy of the swell at the peak frequency cannot be higher than the value of a Pierson-Moskowitz (PM) spectrum (Pierson and Moskowitz, 1964) for the same peak frequency (Portilla et al., 2009). The wave data from 2008 to 2012 and from 2014 to 2015 were used in the study. Since the data of 2013 contain data gaps and are discontinuous, they were not used in the study. The 50th, 75th, 90th and 99th percentile wave heights were also estimated from the half-hourly $H_{\mathrm{m} 0}$ in different years. The percentile values indicate how often the $H_{\mathrm{m} 0}$ was below a particular value. For example, the 50th percentile line indicates that $50 \%$ of the time the $H_{\mathrm{m} 0}$ was less than this value (Sanil Kumar and Anjali Nair, 2015). The seasonal mean wave spectrum was calculated by averaging half-hourly wave spectrum during June-September for each year.

ERA-Interim global atmospheric reanalysis dataset (Dee et al., 2011) of the European Centre for Medium-Range Weather Forecasts (ECMWF) from 1979 to 2015 at location $14.25^{\circ} \mathrm{N}, 74.25^{\circ} \mathrm{E}$ was used to study the longterm variations in the $H_{\mathrm{m} 0}$. Sanil Kumar and Muhammed Naseef (2015) found ERA-Interim $H_{\mathrm{m} 0}$ dataset suitable for the study area. For the study, we have used $H_{\mathrm{m} 0}$ in spatial resolution of $0.5^{\circ} \times 0.5^{\circ}$ and temporal resolution of $6 \mathrm{~h}$. ERAInterim underestimates the extreme wave conditions and has been documented by Stopa and Cheung (2014). Sanil Kumar and Anoop (2015) observed that even though the $H_{\mathrm{m} 0}$ values more than $3.5 \mathrm{~m}$ were underestimated by ERA-Interim data in the AS, Pearson's linear correlation coefficient $(r)$ value for the $H_{\mathrm{m} 0}$ was 0.96 with the measured data with bias value of $-0.17 \mathrm{~m}$, and the difference between the average value of the $H_{\mathrm{m} 0}$ between the measured and ERA-Interim data was less $(\sim 0.2 \mathrm{~m})$. Even though measured altimeter data are available to study the long-term variations in wave height, they are not used in the present study since the $H_{\mathrm{m} 0}$ recorded by the TOPEX and Jason altimeter for the nearshore location in the eastern Arabian Sea shows a larger root-mean-square error $(0.32-0.45 \mathrm{~m})$ than the measured data (Shanas et al., 2014). The time series of the wind speeds (average value for the block $50-75^{\circ} \mathrm{E}$ and $0-15^{\circ} \mathrm{N}$ ) at $850 \mathrm{hPa}$ (LLJ) during the ISM months has been estimated for the years 1979 to 2015 from the ECMWF (Dee et al., 2011) to find its correlation with wave height. A cross-wavelet coherence analysis (Grinsted et al., 2004) was used to find the relationship be-

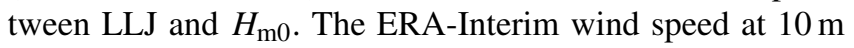
above surface at temporal interval of $6 \mathrm{~h}$ on an approximately $0.5^{\circ}$ grid at $14.25^{\circ} \mathrm{N}, 74.25^{\circ} \mathrm{E}$, close to the wave measurement location was used to study the wind pattern (Dee et al., 2011). The rainfall data for the India Meteorological Department observatory at Honavar during the period 2008 to 2014 were also used in the study.

Oceanic Niño Index $(\mathrm{ONI})$ is the primary indicator for El Niño and La Niña, which are opposite phases of the climate pattern called ENSO. ONI is the 3-month running mean of SST anomalies in the Niño 3.4 region $\left(5^{\circ} \mathrm{N}-\right.$ $\left.5^{\circ} \mathrm{S}, 120-170^{\circ} \mathrm{W}\right)$. ONI, downloaded from the National weather Service, National Oceanic and Atmospheric Administration (http://www.cpc.ncep.noaa.gov/products/analysis monitoring/ensostuff/ensoyears.shtml), is used to examine the influence of ENSO on the $H_{\mathrm{m} 0}$ during the ISM period.

Dipole Mode Index (DMI) is used to study the intensity of the IOD. DMI is represented by anomalous SST gradient between the western equatorial Indian Ocean $\left(50-70^{\circ} \mathrm{E}\right.$ and $10^{\circ} \mathrm{S}-10^{\circ} \mathrm{N}$ ) and the south-eastern equatorial Indian 
Table 1. Average wave statistical parameters during the monsoon period of different years. The values in brackets show the percentage deviation from the mean value during 2008-2015.

\begin{tabular}{|c|c|c|c|c|c|c|c|}
\hline \multirow[t]{2}{*}{ Wave parameter } & \multicolumn{7}{|c|}{ Year } \\
\hline & 2008 & 2009 & 2010 & 2011 & 2012 & 2014 & 2015 \\
\hline$H_{\mathrm{m} 0}(\mathrm{~m})$ & $\begin{array}{r}1.68 \\
(-3.4)\end{array}$ & $\begin{array}{r}1.59 \\
(-8.5)\end{array}$ & $\begin{array}{r}1.73 \\
(-0.5)\end{array}$ & $\begin{array}{l}1.84 \\
(5.8)\end{array}$ & $\begin{array}{l}1.76 \\
(1.2)\end{array}$ & $\begin{array}{r}1.94 \\
(11.6)\end{array}$ & $\begin{array}{r}1.63 \\
(-6.2)\end{array}$ \\
\hline$H_{\max }(\mathrm{m})$ & $\begin{array}{r}2.54 \\
(-4.3)\end{array}$ & $\begin{array}{r}2.42 \\
(-8.8)\end{array}$ & $\begin{array}{c}2.66 \\
(0.3)\end{array}$ & $\begin{array}{l}2.83 \\
(6.7)\end{array}$ & $\begin{array}{r}2.70 \\
(1.8)\end{array}$ & $\begin{array}{r}2.94 \\
(10.8)\end{array}$ & $\begin{array}{r}2.48 \\
(-6.5)\end{array}$ \\
\hline$E_{\max }\left(\mathrm{m}^{2} \mathrm{~Hz}^{-1}\right)$ & $\begin{array}{r}4.43 \\
(-9.6)\end{array}$ & $\begin{array}{r}4.14 \\
(-15.6)\end{array}$ & $\begin{array}{r}4.85 \\
(-1.1)\end{array}$ & $\begin{array}{r}5.50 \\
(12.2)\end{array}$ & $\begin{array}{r}4.86 \\
(-0.9)\end{array}$ & $\begin{array}{r}6.35 \\
(29.5)\end{array}$ & $\begin{array}{r}4.19 \\
(-14.5)\end{array}$ \\
\hline$T_{\mathrm{m} 02}(\mathrm{~s})$ & $\begin{array}{r}6.17 \\
(-2.4)\end{array}$ & $\begin{array}{r}5.99 \\
(-5.2)\end{array}$ & $\begin{array}{r}6.44 \\
(1.9)\end{array}$ & $\begin{array}{r}6.49 \\
(2.7)\end{array}$ & $\begin{array}{r}6.40 \\
(1.3)\end{array}$ & $\begin{array}{r}6.54 \\
(3.5)\end{array}$ & $\begin{array}{r}6.20 \\
(-1.9)\end{array}$ \\
\hline$T_{\mathrm{p}}(\mathrm{s})$ & $\begin{array}{r}11.27 \\
(1.0)\end{array}$ & $\begin{array}{r}11.25 \\
(0.8)\end{array}$ & $\begin{array}{r}10.94 \\
(-2.0)\end{array}$ & $\begin{array}{r}11.03 \\
(-1.2)\end{array}$ & $\begin{array}{r}10.68 \\
(-4.3)\end{array}$ & $\begin{array}{r}11.70 \\
(4.8)\end{array}$ & $\begin{array}{r}11.25 \\
(0.8)\end{array}$ \\
\hline$D_{\mathrm{m}}\left({ }^{\circ}\right)$ & $\begin{array}{r}251 \\
(-1.0)\end{array}$ & $\begin{array}{r}255 \\
(0.6)\end{array}$ & $\begin{array}{r}254 \\
(0.2)\end{array}$ & $\begin{array}{r}255 \\
(0.6)\end{array}$ & $\begin{array}{r}256 \\
(1.0)\end{array}$ & $\begin{array}{r}251 \\
(-1.0)\end{array}$ & $\begin{array}{r}252 \\
(-0.6)\end{array}$ \\
\hline Directional width $\left(^{\circ}\right)$ & $\begin{array}{r}17.23 \\
(7.4)\end{array}$ & $\begin{array}{r}15.50 \\
(-3.3)\end{array}$ & $\begin{array}{r}15.31 \\
(-4.5)\end{array}$ & $\begin{array}{r}15.08 \\
(-6.0)\end{array}$ & $\begin{array}{r}15.23 \\
(-5.0)\end{array}$ & $\begin{array}{r}16.64 \\
(3.8)\end{array}$ & $\begin{array}{r}17.26 \\
(7.6)\end{array}$ \\
\hline Spectral peakedness parameter & $\begin{array}{r}1.81 \\
(-3.9)\end{array}$ & $\begin{array}{r}1.87 \\
(-0.7)\end{array}$ & $\begin{array}{c}1.91 \\
(1.4)\end{array}$ & $\begin{array}{l}1.94 \\
(3.0)\end{array}$ & $\begin{array}{r}1.99 \\
(5.7)\end{array}$ & $\begin{array}{r}1.86 \\
(-1.2)\end{array}$ & $\begin{array}{r}1.80 \\
(-4.4)\end{array}$ \\
\hline Swell (\%) & $\begin{array}{r}71 \\
(-1.6)\end{array}$ & $\begin{array}{r}69 \\
(-4.4)\end{array}$ & $\begin{array}{r}75 \\
(4.0)\end{array}$ & $\begin{array}{r}75 \\
(4.0)\end{array}$ & $\begin{array}{r}74 \\
(2.6)\end{array}$ & $\begin{array}{r}72 \\
(-0.2)\end{array}$ & $\begin{array}{r}69 \\
(-4.4)\end{array}$ \\
\hline Wind-sea $(\%)$ & $\begin{array}{r}29 \\
(4.1)\end{array}$ & $\begin{array}{r}31 \\
(11.3)\end{array}$ & $\begin{array}{r}25 \\
(-10.3)\end{array}$ & $\begin{array}{r}25 \\
(-10.3)\end{array}$ & $\begin{array}{r}26 \\
(-6.7)\end{array}$ & $\begin{array}{r}28 \\
(0.5)\end{array}$ & $\begin{array}{r}31 \\
(11.3)\end{array}$ \\
\hline Short-period waves (\%) & $\begin{array}{r}23.9 \\
(8.0)\end{array}$ & $\begin{array}{r}25.7 \\
(16.1)\end{array}$ & $\begin{array}{r}20.3 \\
(-8.3)\end{array}$ & $\begin{array}{r}20.0 \\
(-9.6)\end{array}$ & $\begin{array}{r}21.2 \\
(-4.2)\end{array}$ & $\begin{array}{r}20.4 \\
(-7.8)\end{array}$ & $\begin{array}{r}23.4 \\
(5.7)\end{array}$ \\
\hline Intermediate-period waves (\%) & $\begin{array}{r}61.9 \\
(-1.8)\end{array}$ & $\begin{array}{r}59.7 \\
(-5.3)\end{array}$ & $\begin{array}{l}64.7 \\
(2.7)\end{array}$ & $\begin{array}{r}66.1 \\
(4.9)\end{array}$ & $\begin{array}{r}67.2 \\
(6.6)\end{array}$ & $\begin{array}{r}60.7 \\
(-3.7)\end{array}$ & $\begin{array}{r}60.9 \\
(-3.4)\end{array}$ \\
\hline Long-period waves (\%) & $\begin{array}{r}14.2 \\
(-4.3)\end{array}$ & $\begin{array}{r}14.6 \\
(-1.6)\end{array}$ & $\begin{array}{l}15.0 \\
(1.1)\end{array}$ & $\begin{array}{r}13.9 \\
(-6.4)\end{array}$ & $\begin{array}{r}11.6 \\
(-21.8)\end{array}$ & $\begin{array}{r}18.9 \\
(27.3)\end{array}$ & $\begin{array}{r}15.7 \\
(5.8)\end{array}$ \\
\hline Wind speed $\left(\mathrm{m} \mathrm{s}^{-1}\right)$ & $\begin{array}{r}6.27 \\
(-2.6)\end{array}$ & $\begin{array}{l}6.59 \\
(2.4)\end{array}$ & $\begin{array}{r}7.05 \\
(9.5)\end{array}$ & $\begin{array}{r}7.19 \\
(11.7)\end{array}$ & $\begin{array}{r}6.46 \\
(0.4)\end{array}$ & $\begin{array}{r}7.24 \\
(12.5)\end{array}$ & $\begin{array}{r}4.26 \\
(-33.8)\end{array}$ \\
\hline
\end{tabular}

Ocean $\left(90-110^{\circ} \mathrm{E}\right.$ and $\left.10^{\circ} \mathrm{S}-0^{\circ} \mathrm{N}\right)$ (Saji et al., 1999). Positive value of DMI is referred to as the positive IOD. DMI can be downloaded from the website http://www.jamstec.go. $\mathrm{jp} / \mathrm{frcgc} / \mathrm{research} / \mathrm{d} 1 /$ iod/DATA/dmi.monthly.txt.

\section{Results and discussion}

\subsection{Wave parameters}

During the ISM, due to the strong cross-equatorial winds of the Findlater/Somali Jet (Findlater 1969), the wave heights are high in the AS (Anoop et al., 2015). The distribution of wave height over different ranges in the study area varies significantly in different years. In most of the years, $30 \%$ of the time, the wave amplitudes $\left(1.5 \mathrm{~m}<H_{\mathrm{m} 0}<2 \mathrm{~m}\right)$ were present except in 2011 and 2014 (Fig. 2a). For the study period, a maximum wave height $\left(H_{\max }\right)$ of $6.8 \mathrm{~m}$ was measured on 4 July 2009, 01:30 UTC, due to deep depression 2009 ARB02, and the corresponding maximum $H_{\mathrm{m} 0}$ was $4.3 \mathrm{~m} . H_{\mathrm{m} 0}$ of $4.3 \mathrm{~m}$ was also measured on 20 June 2015 , 13:30 UTC, due to deep depression 2015 ARB02 (Gujarat Cyclone). The next highest $H_{\mathrm{m} 0}$ of $4.1 \mathrm{~m}$ was measured on 11 June 2014 due to the Tropical Cyclone Nanauk that formed in central AS. The lowest seasonal maximum $H_{\mathrm{m} 0}$ was $3.3 \mathrm{~m}$ in 2012 (Fig. 3). During the 7-year period, inter-annual variations up to $10.8 \%$ were observed in seasonal maximum wave height (Table 1). Seasonal average $H_{\mathrm{m} 0}$ varied from $1.63 \mathrm{~m}$ in 2015 to $1.94 \mathrm{~m}$ in 2014 with a mean value of $1.7 \mathrm{~m}$ (Ta- 

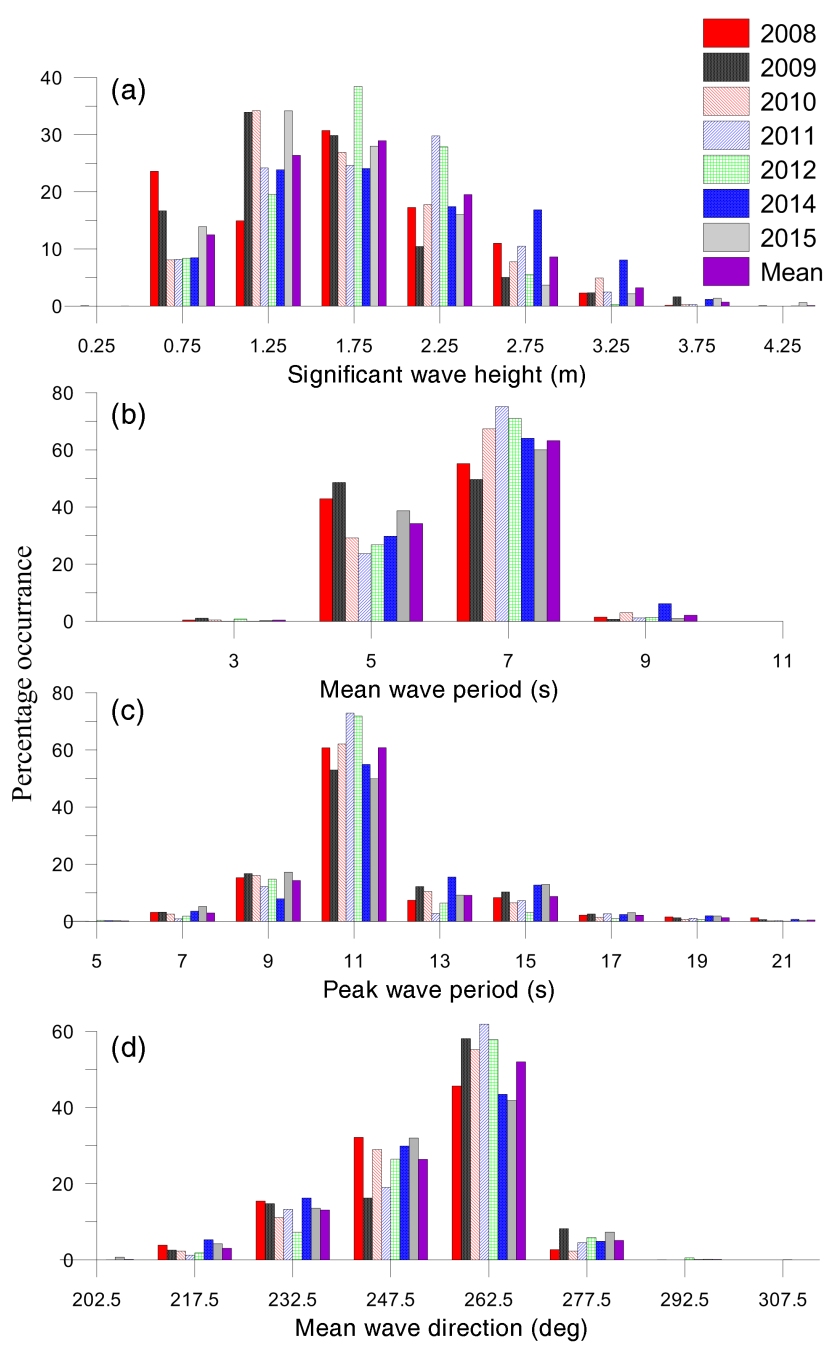

Figure 2. Histogram with the percentage occurrence (a) significant wave heights in bins of $0.5 \mathrm{~m}$, (b) mean wave period in bins of $2 \mathrm{~s}$, (c) peak wave period in bins of $2 \mathrm{~s}$ and (d) mean wave direction in bins of $15^{\circ}$ during June to September in different years.

ble 1). Inter-annual variations up to $11.6 \%$ were observed in seasonal average $H_{\mathrm{m} 0}$ (Table 1). The percentage of higher waves $\left(H_{\mathrm{m} 0}>2.5 \mathrm{~m}\right)$ was more $(\sim 26 \%)$ in 2014 than in other years and was almost double the average percentage of higher waves for all years (Fig. 2a). Hence, 75th percentile, 90th percentile and mean $H_{\mathrm{m} 0}$ were highest $(2.5,3.0$ and $1.9 \mathrm{~m}$ ) in 2014 (Fig. 3). Higher wave heights were least $(\sim 6 \%)$ during 2012 and hence the 25 percentile $H_{\mathrm{m} 0}$ was highest in 2012. A higher percentage $(\sim 24 \%)$ of lower wave heights $(<1 \mathrm{~m})$ were observed in 2008.

The mean wave period was predominant in a narrow range between 4 and $8 \mathrm{~s}$ (Fig. 2b), and inter-annual variations up to $30 \%$ were observed. Like $H_{\mathrm{m} 0}$, higher $T_{\mathrm{m} 02}$ was observed in 2014 and resulted in high 99th, 90th and 75th percentile values in 2014 (Fig. 3). Compared to other years, lower $T_{\mathrm{m} 02}$ was observed in 2009 (Table 1). The peak wave period $\left(T_{\mathrm{p}}\right)$

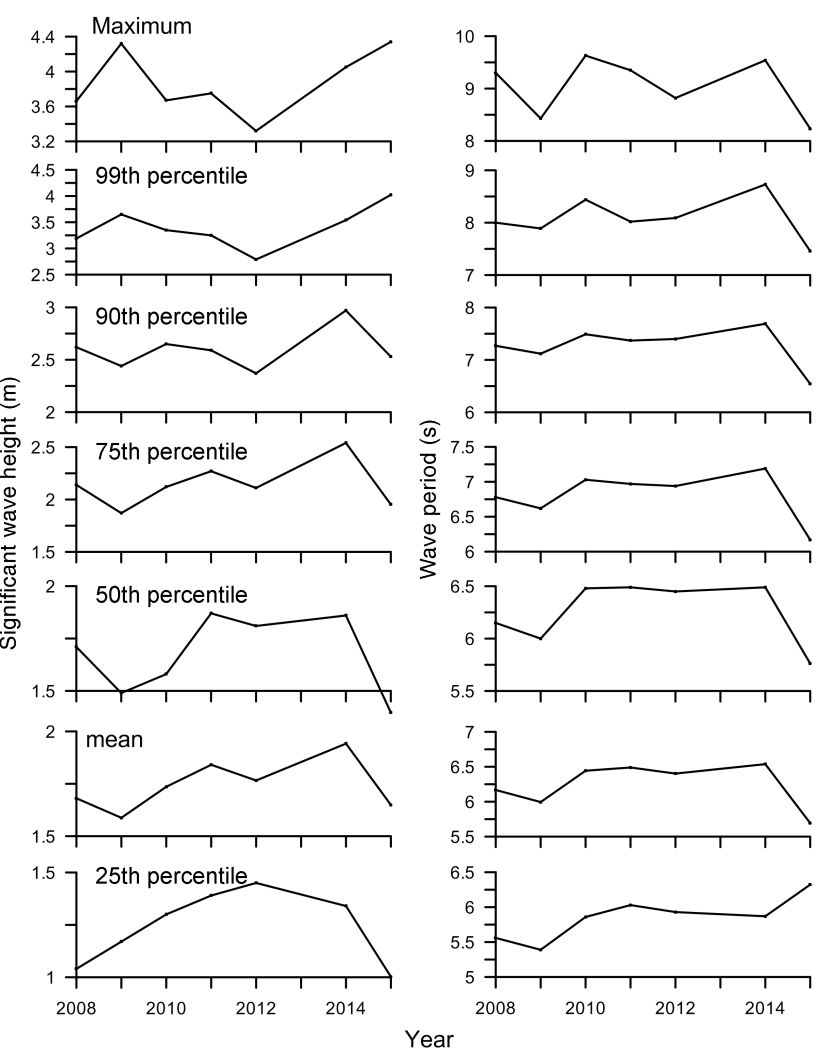

Figure 3. Maximum, 99th percentile, 90th percentile, 75th percentile, 50th percentile, mean and 25th percentile (left panel) significant wave height and (right panel) mean wave period during June to September in different years.

predominantly $(\sim 63 \%)$ varied between 10 and $12 \mathrm{~s}$ with a mean value of $11.2 \mathrm{~s}$ (Fig. $2 \mathrm{c}$ ) and a higher $(\sim 33 \%)$ peak wave period ( $>12 \mathrm{~s}$ ) was observed in 2014. Peak wave periods of more than $18 \mathrm{~s}$ were observed $1.8 \%$ of the time, and long-period waves $\left(T_{\mathrm{p}}>15 \mathrm{~s}\right)$ were observed 2.9 to $9.3 \%$ of the time in monsoon period of different years. During the monsoon period in all the years, the $T_{\mathrm{p}}$ values of the waves were more than $5 \mathrm{~s}$.

Waves were mainly from west-southwest, and hence 50 to $60 \%$ of the time waves were from 255 to $270^{\circ}$ (Fig. 2d). Depth contours of $10 \mathrm{~m}$ and above appear as almost parallel to the shoreline, and the $10 \mathrm{~m}$ depth contour occurs at an average distance of $3.5 \mathrm{~km}$ from the coast. The inclination of the coast is $343^{\circ}$ with respect to true north, and hence the wave direction of $253^{\circ}$ corresponds to the waves approaching parallel to the coastline. Hence, due to refraction, the waves approached the measurement location ( $9 \mathrm{~m}$ water depth) in a narrow range (within $15^{\circ}$ ).

The inter-annual variations were observed on monthly averaged values of all wave parameters (Fig. 4). The variations in the monthly average $H_{\mathrm{m} 0}$ was up to $0.8 \mathrm{~m}$, which is very large since the monthly average values range from 1.15 to $2.45 \mathrm{~m}$ (Fig. 4a). The $H_{\mathrm{m} 0}$ in June was least (monthly av- 

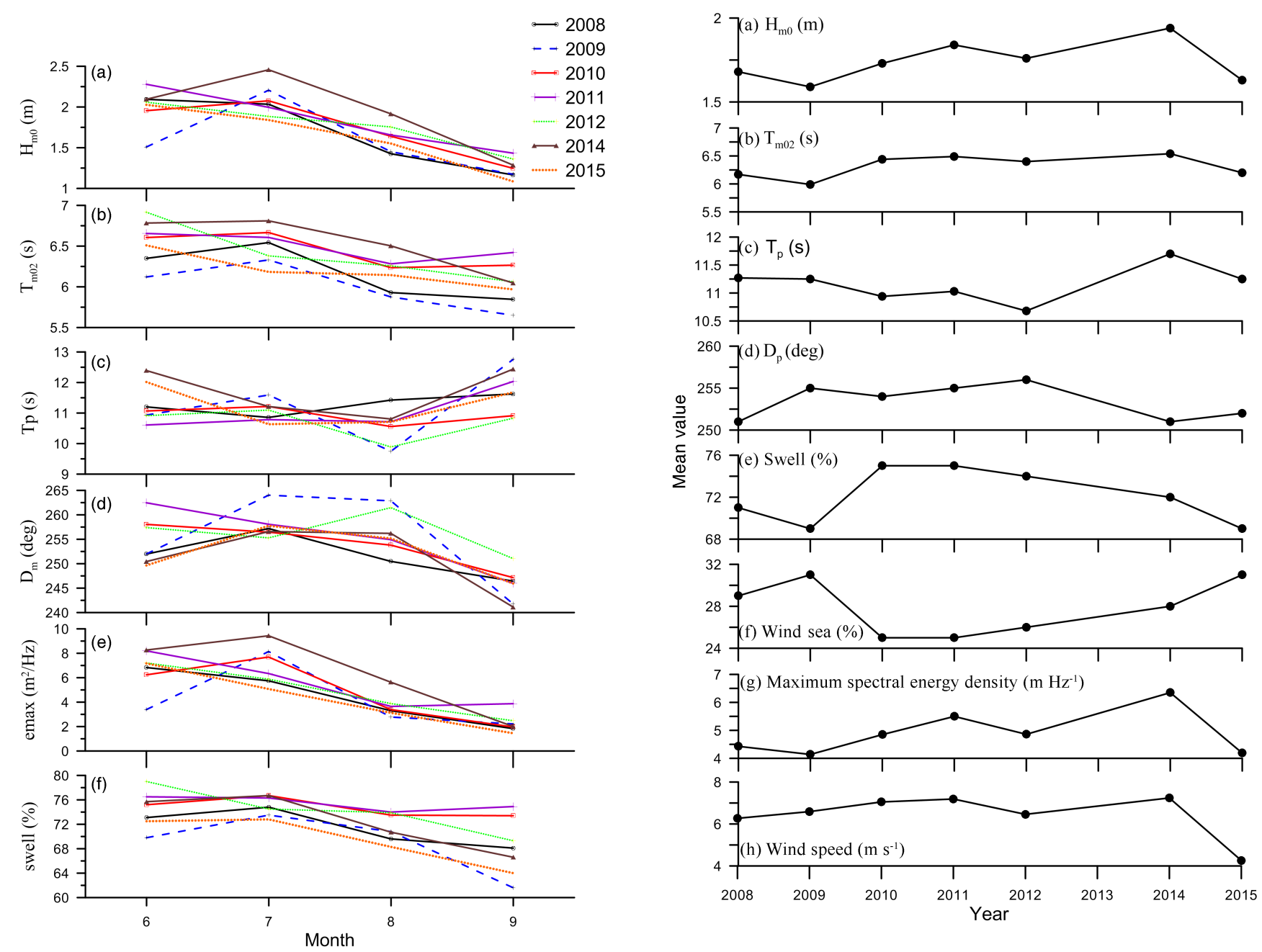

Figure 4. Monthly average wave parameters in different years during June to September: (a) significant wave height, (b) mean wave period, (c) peak wave period, (d) mean wave direction, (e) maximum spectral energy density and (f) swell percentage.

erage $\sim 1.51 \mathrm{~m})$ in 2009 due to the delayed monsoon compared to other years (Sanil Kumar and Anjali Nair, 2015) and resulted in large inter-annual variation in average monthly value in June. In June, Chempalayil et al. (2012) also noted the large variation in the monthly average value of $H_{\mathrm{m} 0}$ during 2008-2010. Higher values of monthly average $H_{\mathrm{m} 0}$ were observed in July except in 2011 and 2012. The $H_{\mathrm{m} 0}$ values in July and August were high during 2014, resulting in higher seasonal average value in 2014. In the month of September, late monsoon period, the wave heights were lowest compared to other monsoon months. The seasonal average $H_{\mathrm{m} 0}$ covering all years was $1.76 \mathrm{~m}$, and the corresponding $H_{\max }$ was $2.65 \mathrm{~m}$. The inter-annual variations in seasonal average $H_{\mathrm{m} 0}$ in monsoon were high $(\sim 11.5 \%)$ in 2014 and less $(<6 \%)$ 2010 to 2012 (Fig. 5a) due to the inter-annual variations in seasonal mean wind speed (Fig. 5h). The higher wave heights during 2014 were due to the higher wind speed (average wind

speed $\sim 7.3 \mathrm{~m} \mathrm{~s}^{-1}$ ) in 2014 compared to other years (6.3 to $7.2 \mathrm{~m} \mathrm{~s}^{-1}$ ) (Fig. 5h). The variations in $E_{\max }$ were similar to the variations in $H_{\mathrm{m} 0}$, low values of $E_{\max }$ were observed in June 2009, and the $E_{\max }$ was high during 2014 in all the months except in September (Fig. 4e).

The inter-annual variations up to $0.8 \mathrm{~s}$ were observed in the monthly average $T_{\mathrm{m} 02}$ (Fig. 4b). In seasonal average $T_{\mathrm{m} 02}$, the inter-annual variations were similar to the variations in $H_{\mathrm{m} 0}$ (Fig. 5b). Variations in monthly average $T_{\mathrm{p}}$ were up to $1.7 \mathrm{~s} \mathrm{(Fig.} \mathrm{4c).} \mathrm{The} T_{\mathrm{p}}$ values were higher in September due to the decrease in monsoon intensity and in turn the reduction of wind seas (Fig. 4c). The seasonal average value of $T_{\mathrm{p}}$ was low $(\sim 10.9 \mathrm{~s})$ during 2012 to 2012 and was high $(\sim 11.7 \mathrm{~s})$ during 2014 (Fig. 5c).

Inter-annual variations up to $10^{\circ}$ were observed in the mean wave direction (Fig. 5d). In September, the direction of incoming waves shifted to the southwest from the west- 


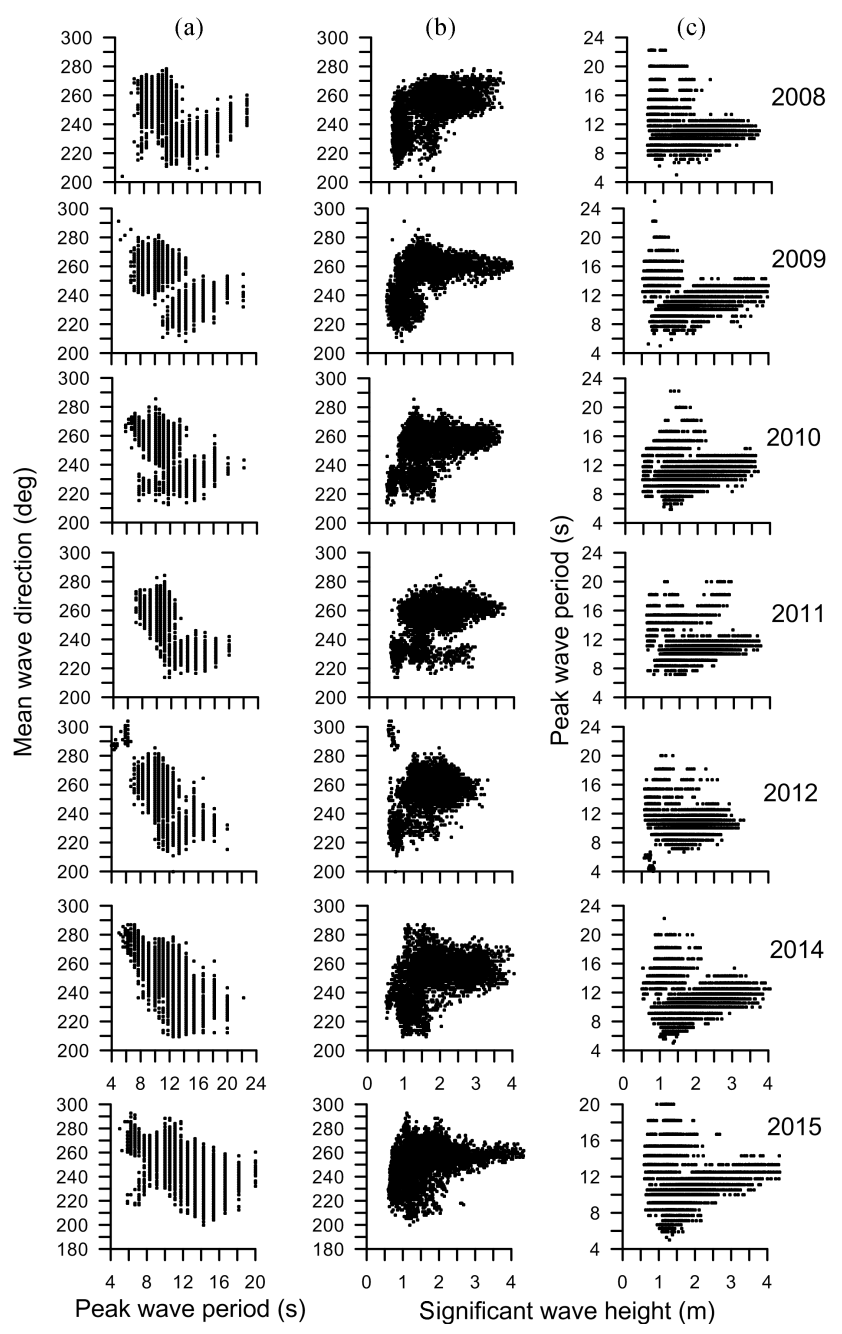

Figure 6. Scatter plot of (a) peak wave period and mean wave direction, (b) significant wave height and mean wave direction and (c) significant wave height and peak wave period in different years.

southwest direction observed in other monsoon months due to the reduction in monsoon intensity (Fig. 4d). High waves became refracted and were from the west-southwest at $9 \mathrm{~m}$ water depth. The variation of the seasonally average $E_{\max }$ was similar to the variation of $H_{\mathrm{m} 0}$ and was higher in 2014 (Fig. 5g). In 2009 and 2015, the monthly average and seasonal average percentage of the swell were lower compared to other years (Figs. 4f and 5e). The percentage of monthly average swells varied up to $10 \%$ inter-annually, and the percentage of swells was higher in 2010 and 2011; hence the wind seas were low during these years (Fig. 5f).

The scatter plot of peak wave period and mean wave direction indicates that the southwest waves have high peak wave period ( $>10 \mathrm{~s}$ ) and northwest waves have low peak wave period (Fig. 6a). High peak wave period from the southwest was due to the larger fetch available in that direction compared to other directions. The study area is exposed to waves from south to northwest, and the land mass is $\sim 9000 \mathrm{~km}$ in the south, $\sim 4000 \mathrm{~km}$ in the southwest, $\sim 2010 \mathrm{~km}$ in the west and $\sim 1600 \mathrm{~km}$ in the northwest (Amrutha et al., 2016). Due to the wave refraction, the high waves $\left(H_{\mathrm{m} 0}>3 \mathrm{~m}\right)$ from south-southwest became refracted to west-southwest at $9 \mathrm{~m}$ water depth (Fig. 6b). Two different patterns are observed in the scatter plot of $T_{\mathrm{p}}-H_{\mathrm{m} 0}$ : swells with a period of more than $15 \mathrm{~s}$ have a different pattern to that of those with periods of less than $15 \mathrm{~s}$. Long-period waves $\left(T_{\mathrm{p}}>18 \mathrm{~s}\right)$ observed were mainly with $H_{\mathrm{m} 0}<2 \mathrm{~m}$ (Fig. 6c).

Figure 7 represents the time series plot of wind-sea $H_{\mathrm{m} 0}$ during the monsoons in different years along with wind and rainfall data. The $H_{\mathrm{m} 0}$ of wind sea follows the monsoon wind pattern in all years indicating that even though swells were dominating during the monsoon, the waves were forced to some extent by the local winds also. The correlation between the daily average $H_{\mathrm{m} 0}$ and the daily rainfall was poor (Pearson's linear correlation coefficient varies from 0.35 to $0.63)$. The maximum daily rainfall $(\sim 221 \mathrm{~mm})$ during $2008-$ 2015 was on 3 July 2009 and the maximum wave height ( $\sim 6.9 \mathrm{~m}$ ) was on 4 July 2009. During 2008-2015, the total seasonal rainfall at Honavar varied from $2629 \mathrm{~mm}$ (in 2015) to $4083.8 \mathrm{~mm}$ (in 2011). Anoop et al. (2015) observed that the rainfall data of the west coast of India show a larger resemblance with principal component time series of box average $H_{\mathrm{m} 0}$ in central AS $\left(10-15^{\circ} \mathrm{N}, 60-65^{\circ} \mathrm{E}\right)$ than compared to the rainfall over the entire Indian land mass because the all-India rainfall will contain the northeast monsoon (October-December) especially for the eastern side of India. The time series data on wind-sea $H_{\mathrm{m} 0}$ show oscillations with periods of 5-20 days.

The localized intermittent periodicities can be identified using wavelet transforms, which expand time series into time frequency space. The continuous wavelet transform expands a time series into a time frequency space where oscillations with different periods can be seen. The continuous wavelet power spectra of half-hour $H_{\mathrm{m} 0}$ during monsoon in different years are presented in Fig. 8. We can see two bands of oscillations: one in the 8-16-day band and the other one in the 48-day band. Among these two bands, the energy in 8-16-day band was continuous. For the year 2008 (Fig. 8a) high power concentration was observed in the 8-16-day band during August. Interestingly, in the year 2009 (Fig. 8b), a monsoon deficient year, no high power concentration was observed, but 4-8-day and 8-16-day bands with lower power concentration were observed in June-July. For the year 2010 (Fig. 8c) high power concentration was observed for 8-14-day and 16-22-day bands during June-July, which further extends throughout the monsoon period with low strength. During 2011 (Fig. 8d), the 16-22-day band observed for the previous year was shifted to July-August. A 10-14-day band was also observed during September. For the year 2012 (Fig. 8e), a 14-20-day band was observed during July followed by a 2540-day band which extends to the month of August also. A 20-30-day band was observed during July for the year 2014 


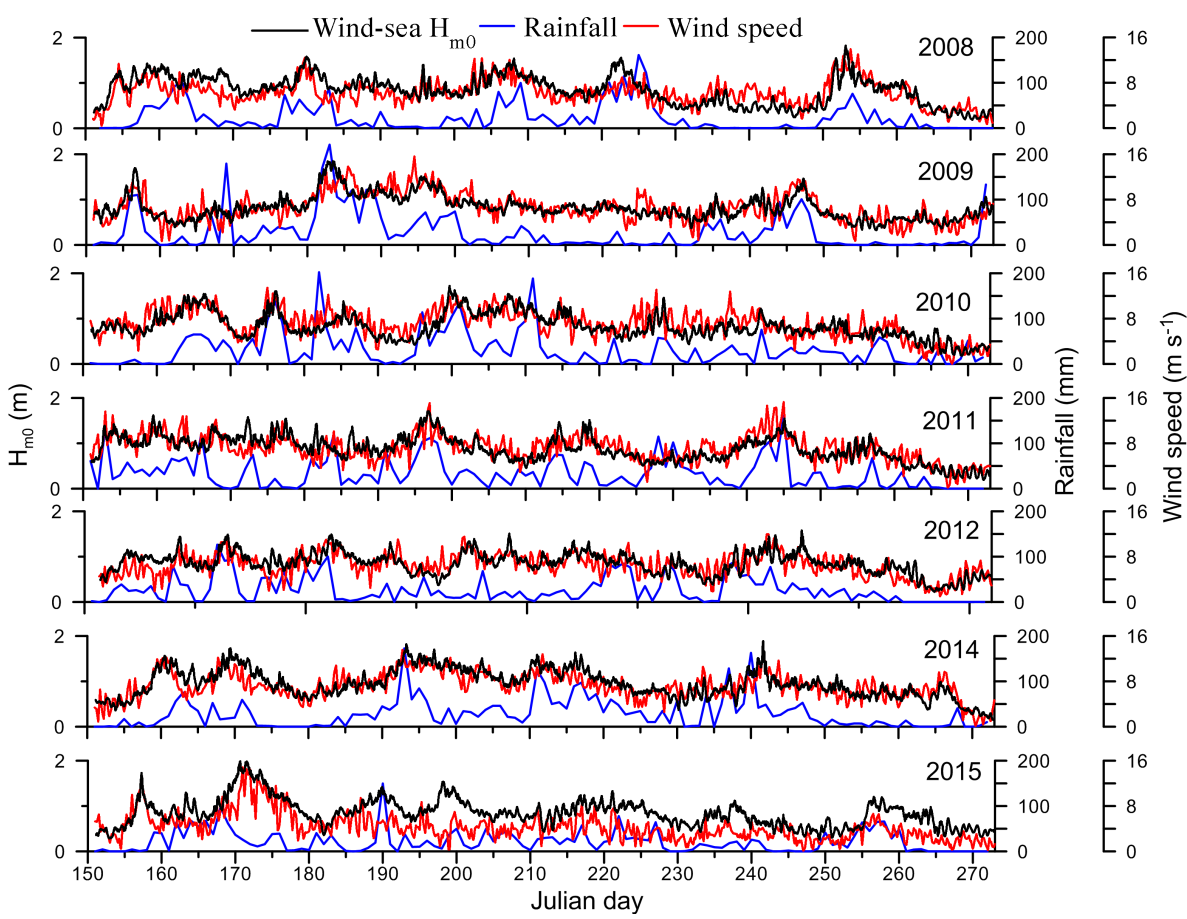

Figure 7. Time series plot of significant wave height of wind sea, wind speed at $10 \mathrm{~m}$ above surface and rainfall during 1 June to 30 September in different years.

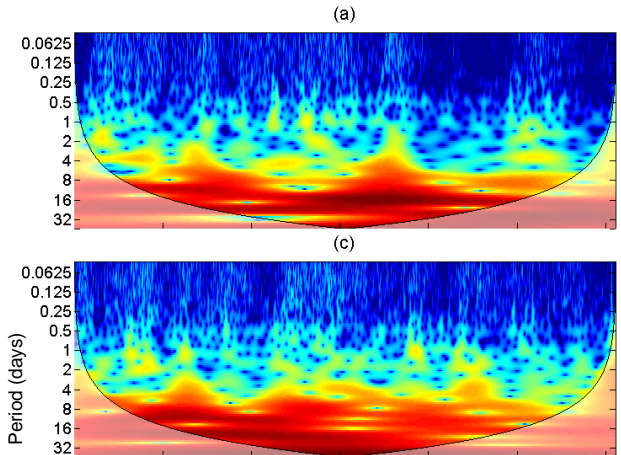

(e)

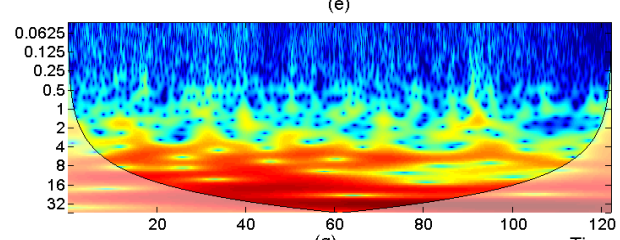

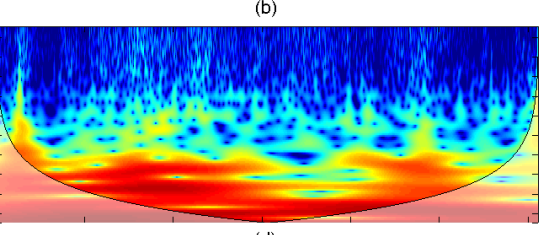

(d)

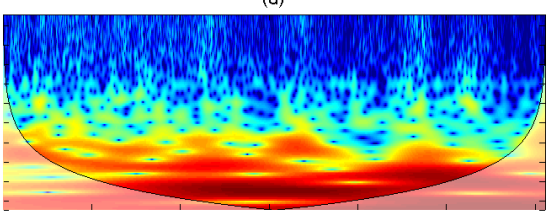

(f)

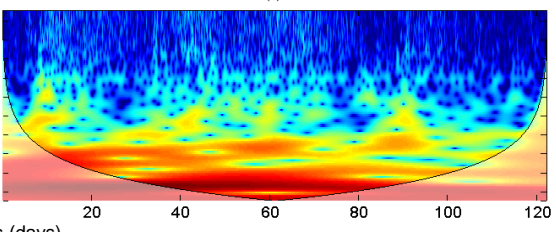

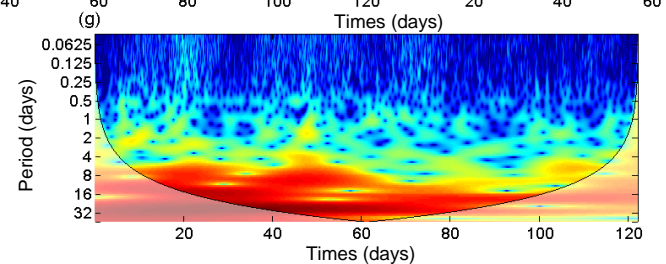
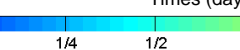

Figure 8. Continuous wavelet power spectrum of half-hour significant wave height during monsoon for the years (a) 2008, (b) 2009, (c) 2010, (d) 2011 , (e) 2012 and (f) 2014 and (g) 2015. 


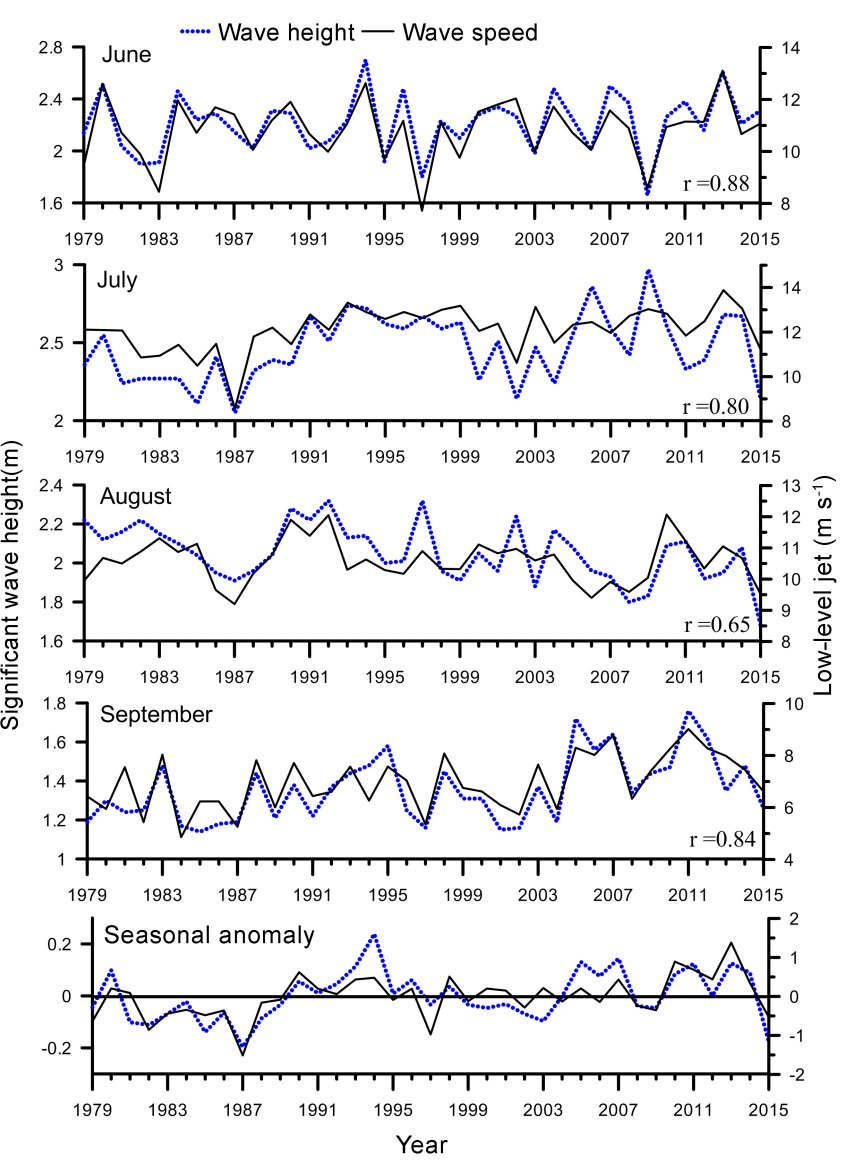

Figure 9. Time series plot of monthly average significant wave height and wind speed at $850 \mathrm{hPa}$ (LLJ) during June to September. The bottom graph shows the time series plot of seasonal anomaly of significant wave height and wind speed.

(Fig. 8f) which was again observed during 2015 (Fig. 8g). In a nutshell, most of the power was concentrated in the 8-16day bands. The oscillations in $H_{\mathrm{m} 0}$ were mainly due to the change in the monsoon intensity. Kulkarni et al. (2011) reported that the intra-seasonal behaviour on ISM was mainly dominated by two modes 30-60 and 10-20 days, and these two periods have been related to the active and break cycles of the monsoon rainfall over the Indian subcontinent (Kulkarni et al., 2011). The magnitude of wind reduces during the break periods and influenced the waves and resulted in 8 16-day oscillations. Day-to-day fluctuations of weather with timescales of 5-7 days were reported by Raju et al. (2005) and resulted in 4-8-day oscillations in the wave height.

\subsection{Wave height and low-level jet}

During the summer monsoon, winds at lower levels dominate the AS, and the LLJ is the dominant lower tropospheric circulation over the AS (Joseph and Sijikumar, 2004). Therefore, we examined the monthly average LLJ during 1979 to 2015 with the monthly average $H_{\mathrm{m} 0}$ (Fig. 9). Our results show high positive correlations between LLJ and $H_{\mathrm{m} 0}(r \sim 0.84)$ for all the months except for August $(r \sim 0.66)$. The LLJ shows its peak mostly for the month of July and decreases gradually for the following months which were similar to the variation in $H_{\mathrm{m} 0}$ (Fig. 9). The standard deviation of the inter-annual variability of the seasonal average $H_{\mathrm{m} 0}$ is around $5 \%$ of the mean summer $H_{\mathrm{m} 0}$. The seasonal anomaly of $H_{\mathrm{m} 0}$ also follows the pattern of the seasonal anomaly in LLJ. During 1979-2015, the strongest negative anomaly $(\sim 0.2 \mathrm{~m})$ in seasonal average $H_{\mathrm{m} 0}$ is observed in 1987 and the positive anomaly $(\sim 0.24 \mathrm{~m})$ in 1994 . For LLJ, the strongest negative anomaly $\left(\sim 1.5 \mathrm{~m} \mathrm{~s}^{-1}\right)$ also was in 1987 , but the strongest positive anomaly ( $\sim 1.4 \mathrm{~m} \mathrm{~s}^{-1}$ ) was in 2013 (Fig. 9).

The wavelet coherence is a powerful method for testing proposed linkages between two time series. We used wavelet coherence (WTC) (Grinsted et al., 2004) to examine the phase relationship that exists between the LLJ and $H_{\mathrm{m} 0}$. Figure 10 displays the WTC during monsoon period for the years 2008-2015 (year 2013 not included). It is evident from the figure that LLJ and $H_{\mathrm{m} 0}$ were in-phase related (phase angle $0^{\circ}$ ) almost all the time. Time lag between the two time series is represented by the phase angle. Zero indicates when the two time series are coincident in time (i.e. in-phase), and it will be around $180^{\circ}$ if they are in anti-phase (when one is maximum, the other is minimum and vice versa). Outside, the area with low coherency also shows predominantly in-phase relations. The phase relationship indicates that LLJ leads $H_{\mathrm{m} 0}$. The coherency was greater than 0.8 most of the time in the 10-30-day band, which sometimes exceeds more than 0.9 for the years 2009, 2014 and 2015. In certain regions of the 10-30-day band, a downward phase angle (approximately $90^{\circ}$ ) was also observed, suggesting that the LLJ leads $H_{\mathrm{m} 0}$ by approximately $90^{\circ}$ during this period.

\subsection{Influence of ENSO, IOD and SAM}

We used ONI to study the influence of ENSO on the wave height of the study area since ENSO is one of the main modes of inter-annual variability of ISM. The time series plot of monthly anomaly of $H_{\mathrm{m} 0}$ during June to September and the seasonal average is presented in Fig. 11 along with the ONI. An inverse relationship is observed between the seasonal anomaly of $H_{\mathrm{m} 0}$ and ONI. It is already known that ENSO has a negative relationship with ISM and is linked to the modulation of the Walker circulation (Cherchi and Navarra, 2013). High ONI indicates strong El Niño years and is expected to have a weak monsoon (Cherchi and Navarra, 2013). Based on ONI, the events are classified as weak (with a $0.5-0.9$ SST anomaly), moderate (1.0-1.4), strong (1.5$1.9)$ and very strong $(\geq 2.0)$ events. Very strong El Niño years are 1982-1983, 1997-1998 and 2015-2016 and moderate years are 1986-1987, 1987-1988, 1991-1992, 20022003 and 2009-2010 (Fig. 12). Figure 11 shows that $H_{\mathrm{m} 0}$ is relatively low during the strong El Niño years and the low 

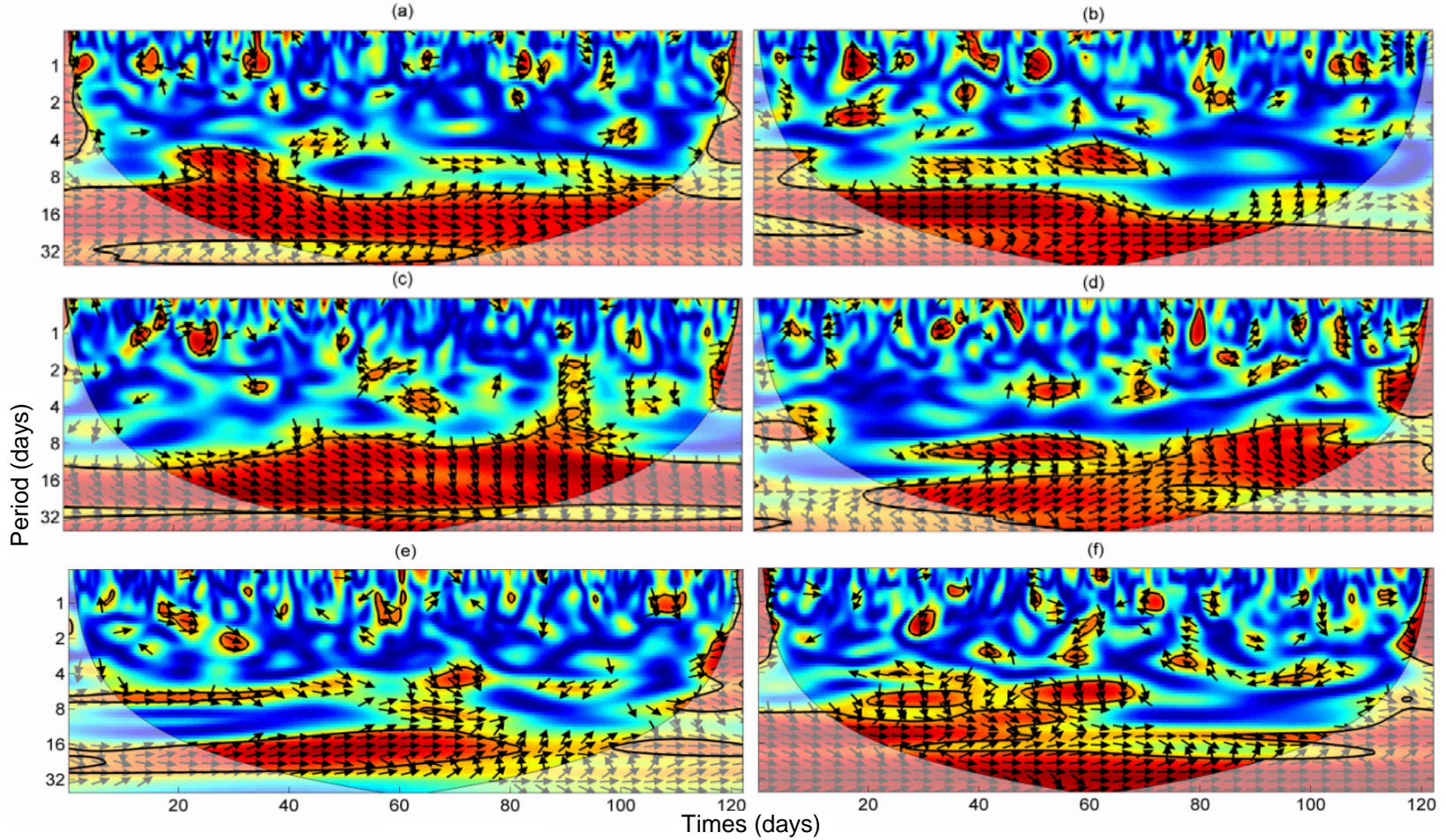

(g)
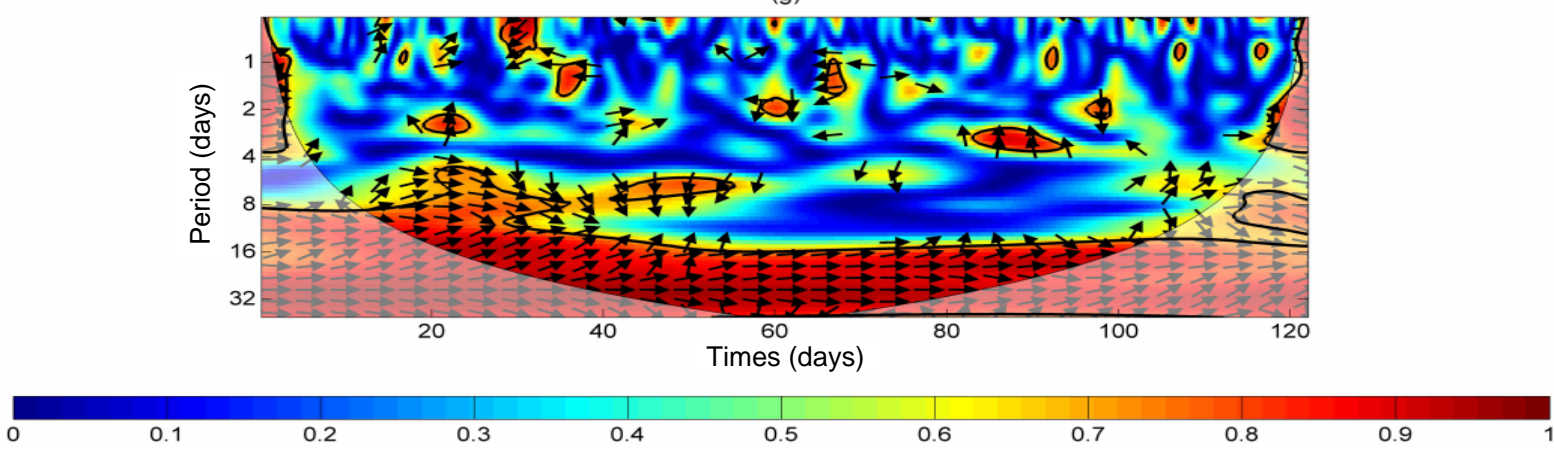

Figure 10. Wavelet coherence of LLJ and $H_{\mathrm{m} 0}$ for the years (a) 2008, (b) 2009, (c) 2010, (d) 2011, (e) 2012, (f) 2014 and (g) 2015 . The $5 \%$ significance level against red noise is shown as a thick contour. The relative phase relationship is shown as arrows (with in-phase pointing right, anti-phase pointing left, and LLJ leading $H_{\mathrm{m} 0}$ by $90^{\circ}$ by straight down).

values are due to the weakening of westerly winds over the Indian Ocean due to El Niño (Reason et al., 2000).

The Anoop et al. (2016) study highlights the role of IOD in wave climate variability due to changes in the equatorial SST and sea level pressure. Since the wind is the major generating force of surface waves in the ocean, the wind anomaly caused by IOD (Schott et al., 2009) induces the change in wave climate. During 1982, 1987, 1997 and 2015, which are the positive IOD years, an inverse relationship is observed between the seasonal anomaly of $H_{\mathrm{m} 0}$ and DMI (Fig. 13a). The reduction in wave height in the study area during positive IOD is due to weaker zonal wind shear (Cherchi and Navarra, 2013) and reduction in wind seas, as observed by Anoop et al. (2016).
SAM is the principal mode of variability in the atmospheric circulation of the Southern Hemisphere (Hemer et al., 2010). Based on the satellite altimeter data, Hemer et al. (2010) reported that the wave climate variability in the Southern Hemisphere is correlated with the SAM, particularly during austral autumn (March-May) and winter (JuneAugust) months. Izaguirre et al. (2011) observed that SAM presents a widespread influence on waves along the Southern Ocean, South Indian Ocean, and the South Atlantic Ocean. Inter-annual variability is greatest in the Indian Ocean sector of the Southern Ocean during the winter months (Hemer et al., 2010). Earlier studies have indicated that the waves in the study area are significantly affected by remotely generated swells and reported the presence of swells from the South- 


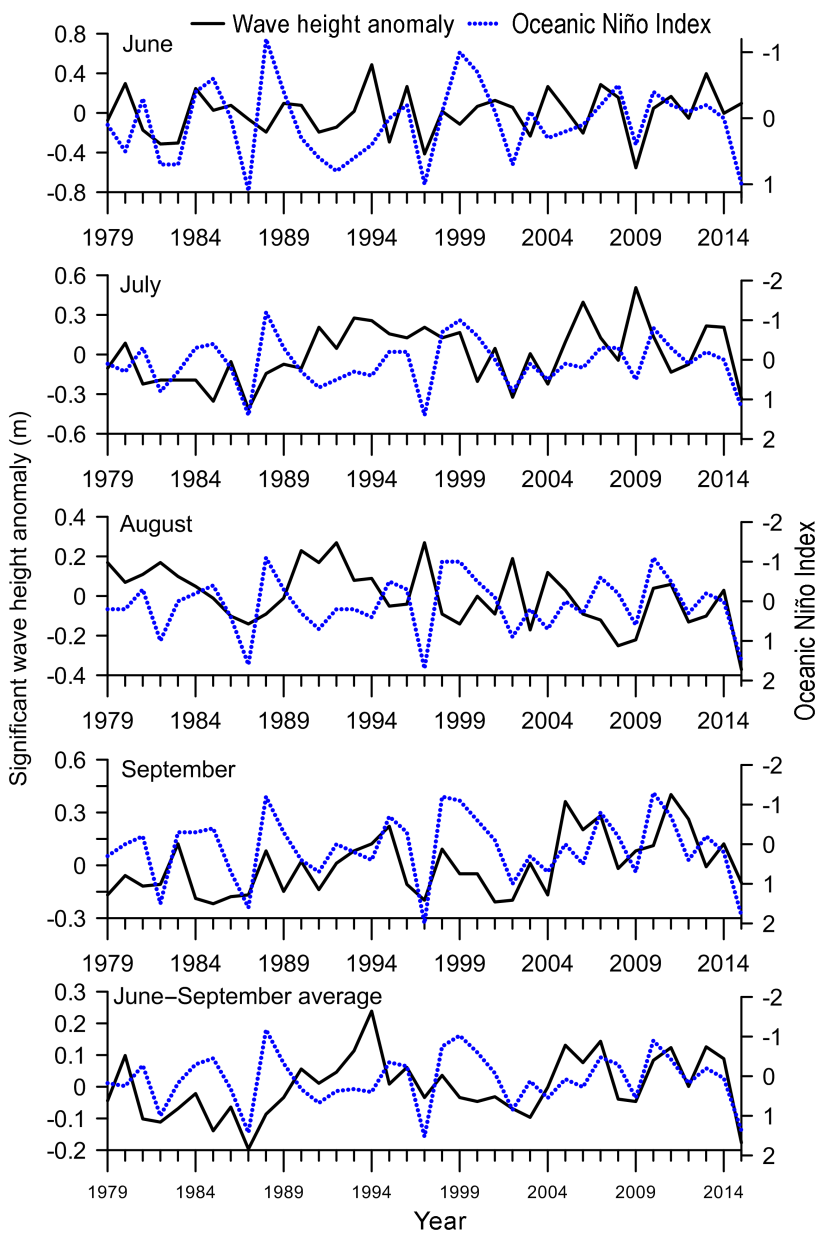

Figure 11. Time series of the significant wave height anomaly (black line) during June to September and the average during June to September along with Oceanic Niño Index (blue dotted line)

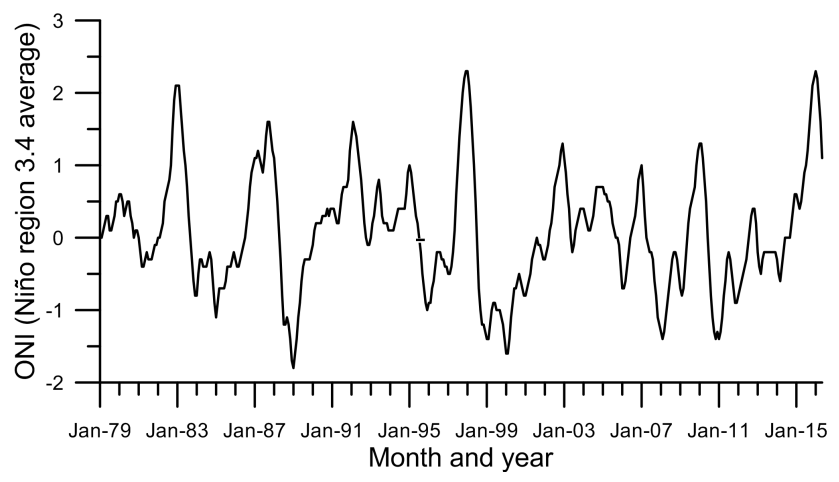

Figure 12. Time series of the 3-monthly average Oceanic Niño Index in different months from January 1979 to December 2015.

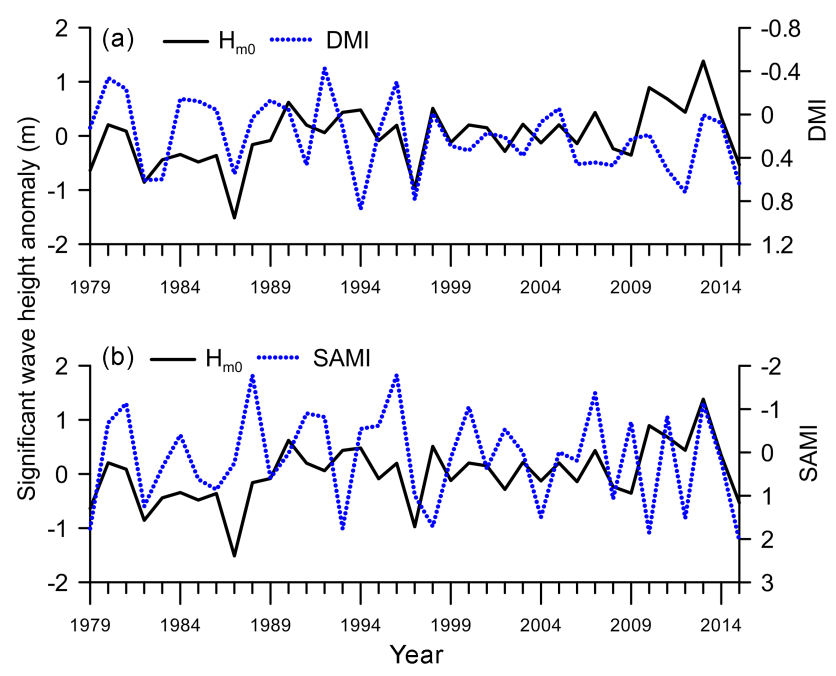

Figure 13. Time series of the monsoon seasonal average significant wave height anomaly with (a) Dipole Mode Index (DMI) and (b) Southern Annular Mode Index (SAMI).

ern Ocean in the eastern AS (Glejin et al., 2013; Anoop et al., 2015). Hence, we have examined the monsoon seasonal anomaly of $H_{\mathrm{m} 0}$ with SAM Index (SAMI). Except during 1979, 1982, 2013 and 2015, the influence of SAM on the monsoon waves is not observed (Fig. 13b). Perhaps the long period oscillations illustrated in Fig. 8 are related to the MJO, but this requires further study.

\subsection{Wave spectrum}

The spectral representation of the sea states during monsoon is an input for estimation of induced loads on ocean structures and is also used to recognize the various wave systems at a location. The time series plot of the spectral energy density with frequency during monsoon for 2008 to 2012 and 2014 to 2015 is presented in Fig. 14. During June to August, the wave spectra were narrow-banded, having energy density mainly between frequency 0.07 and $0.12 \mathrm{~Hz}(\sim 14$ and $8 \mathrm{~s})$ (Sanil Kumar and Anjali Nair, 2015). The seasonal average maximum spectral energy density varied from $4.14 \mathrm{~m}^{2} \mathrm{~Hz}^{-1}$ in 2009 to $6.35 \mathrm{~m}^{2} \mathrm{~Hz}^{-1}$ in 2014 (Table 1). The spectral peakedness parameter was used for quantifying the narrowness of the wave spectrum along the eastern AS (Sanil Kumar et al., 2014). The wave spectra were narrow and peaked during the monsoon period with a relatively high (1.81-1.99) spectral peakedness parameter (Table 1). In the seasonal average spectra, inter-annual variations were observed with maximum variations in frequency 0.06 to $0.09 \mathrm{~Hz}$ (Fig. 15a). The contribution of intermediate period waves (period 6 to $12 \mathrm{~s}$ ) varied from 59.7 to $67.2 \%$ in different years and was highest in 2012 (Table 1). Inter-annual variations in spectral peak were from 0.086 to $0.098 \mathrm{~Hz}$. The high-frequency tail of the wave spectra follows $f^{-3}$ from 0.1 to $0.35 \mathrm{~Hz}$; for frequencies above $0.35 \mathrm{~Hz}$, it follows $f^{-4}$, where $f$ is the fre- 
Table 2. Number of single-peaked and multi-peaked wave spectra in different years.

\begin{tabular}{lrrrr|rrrr}
\hline Year & \multicolumn{3}{c|}{ Single peak } & \multicolumn{4}{c}{ Multi-peak } \\
\cline { 2 - 9 } & Total & $\begin{array}{r}\text { Wind sea } \\
\text { dominated } \\
\left(T_{\mathrm{p}}<6\right)\end{array}$ & $\begin{array}{r}\text { Swell } \\
\text { dominated } \\
\left(T_{\mathrm{p}}>8\right)\end{array}$ & $\begin{array}{r}\text { Mixed } \\
\left(6<T_{\mathrm{p}}<8\right)\end{array}$ & Total & $\begin{array}{r}\text { Wind sea } \\
\text { dominated } \\
\left(T_{\mathrm{p}}<6\right)\end{array}$ & $\begin{array}{r}\text { Swell } \\
\text { dominated } \\
\left(T_{\mathrm{p}}>8\right)\end{array}$ & $\begin{array}{r}\text { Mixed } \\
\left(6<T_{\mathrm{p}}<8\right)\end{array}$ \\
\hline 2008 & 3304 & 0 & 3300 & 4 & 2551 & 1 & 2365 & 185 \\
2009 & 3335 & 0 & 3325 & 10 & 2509 & 3 & 2323 & 183 \\
2010 & 3672 & 0 & 3664 & 8 & 2132 & 3 & 1985 & 144 \\
2011 & 3997 & 0 & 3996 & 1 & 1859 & 0 & 1806 & 53 \\
2012 & 3804 & 0 & 3799 & 5 & 2052 & 23 & 1926 & 103 \\
2014 & 3552 & 0 & 3543 & 9 & 2303 & 16 & 2081 & 206 \\
2015 & 3064 & 0 & 3053 & 11 & 2783 & 17 & 2468 & 298 \\
\hline Average & 3533 & 0 & 3526 & 7 & 2313 & 9 & 2136 & 167 \\
\hline
\end{tabular}

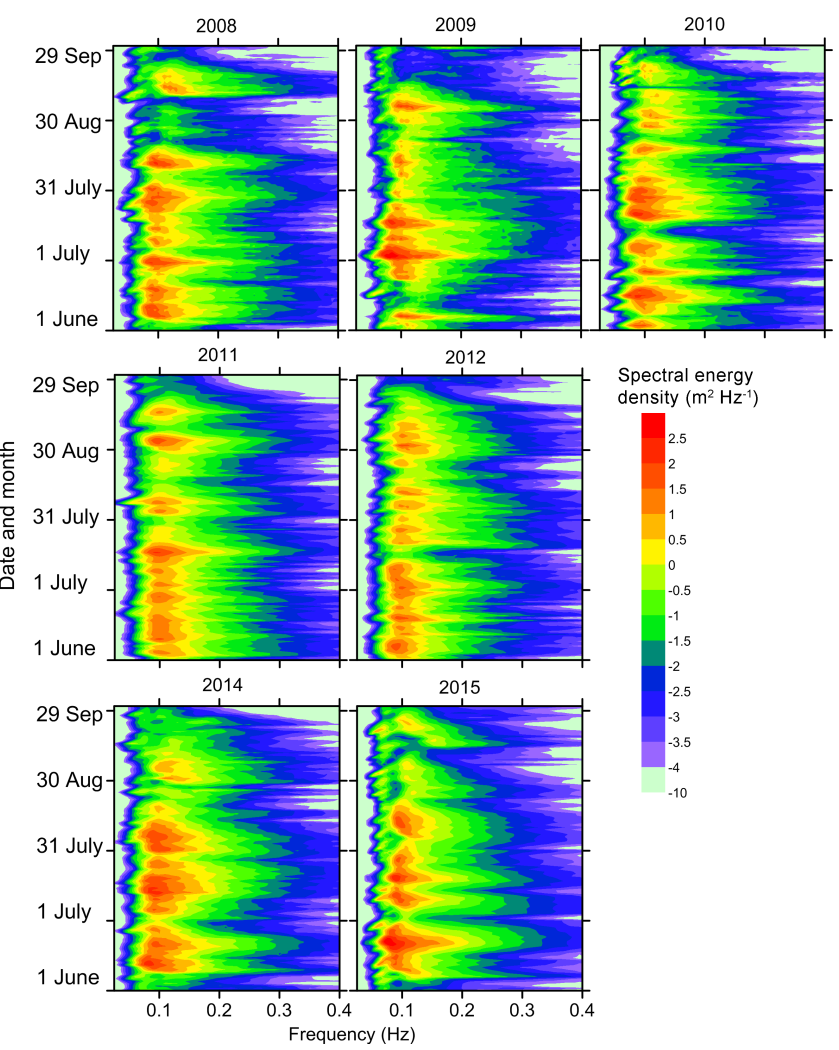

Figure 14. Contour plots of spectral energy density in logarithmic scale (base 10) with frequency and time during different years.

quency. In the high-frequency part, the exponent of spectral curve is approximately -3 in finite depth and -5 in deep water (Young and Verhagen, 1996). The variations in the direction of swell waves (frequencies 0.08 to $0.14 \mathrm{~Hz}$ ) in different years were marginal $\left(<5^{\circ}\right)$ since these waves are refracted waves measured at $9 \mathrm{~m}$ water depth, whereas significant variations $\left(\sim 20^{\circ}\right)$ were observed in the higher $(>0.4 \mathrm{~Hz})$ and lower $(<0.05 \mathrm{~Hz})$ frequency (Fig. 15b).
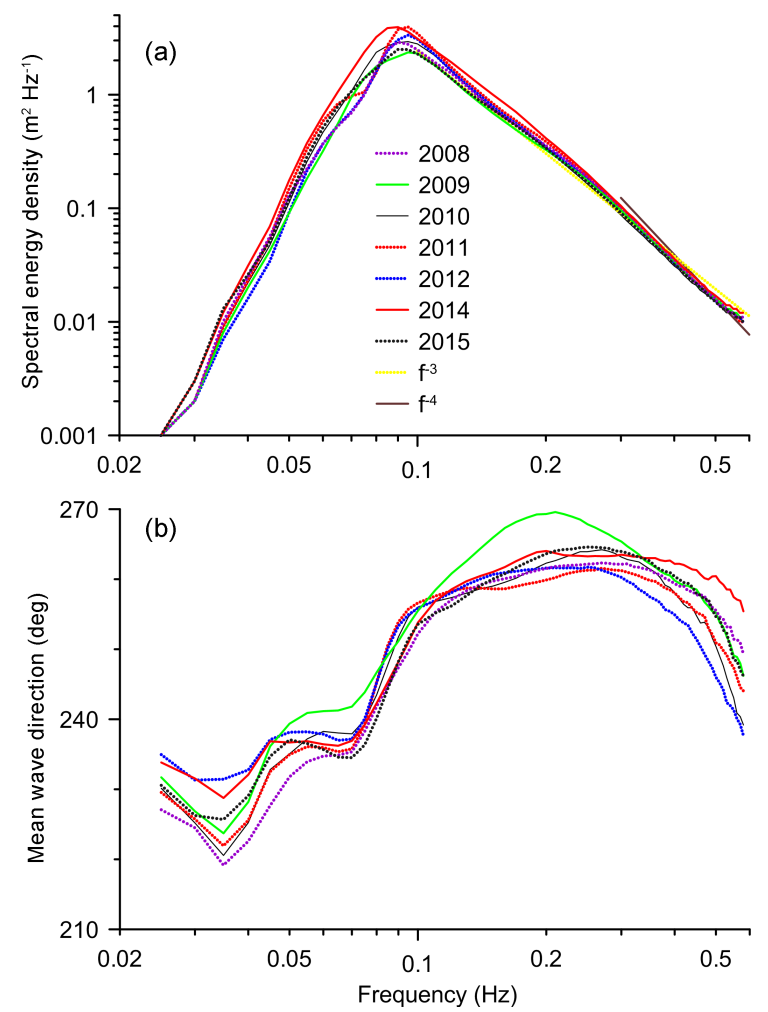

Figure 15. (a) Average wave spectrum and (b) mean wave direction during June to September in different years.

In real sea conditions the wave energy is distributed not only in the frequency domain but also in direction. The directional wave spectra represent the contributions of waves propagating in different directions with different wave lengths. The averaged wave directional spectrum during monsoon was estimated to study the variations of spectral energy density during 2008-2012 and 2014-2015 (Fig. 16). During the monsoon period, the spectral energy density was mainly in a narrow range $\left(0.07\right.$ to $0.14 \mathrm{~Hz}$ and 240 and $\left.280^{\circ}\right)$. 


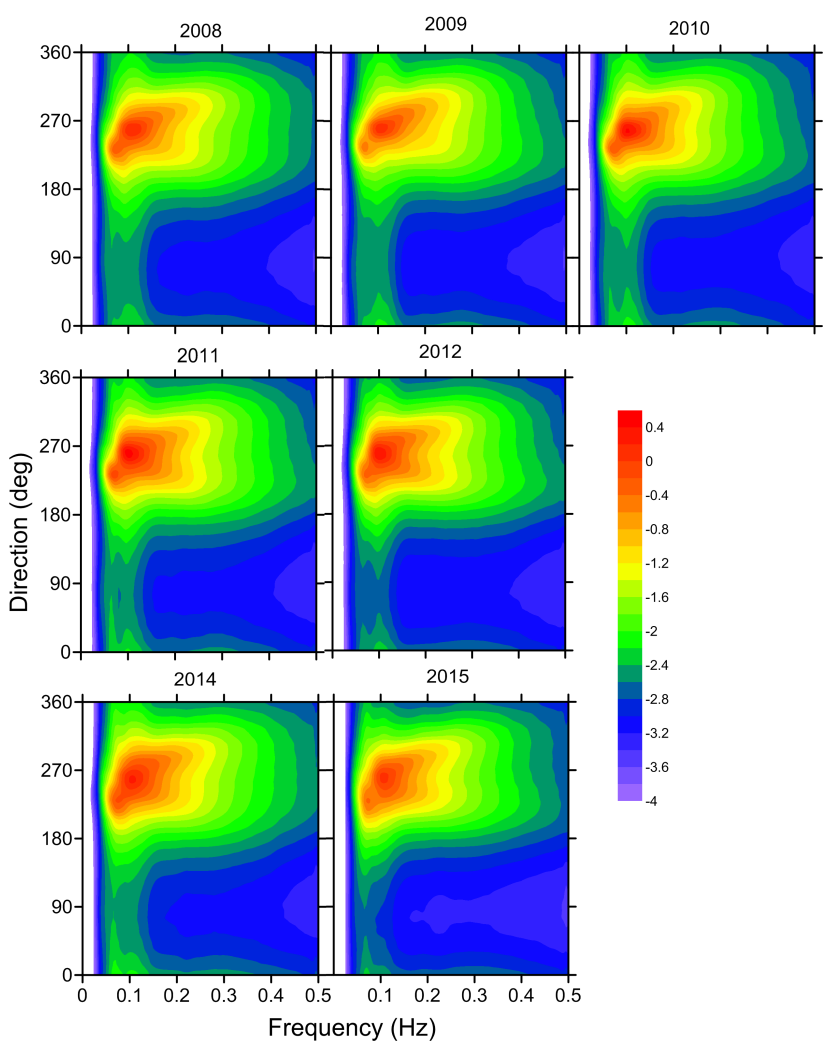

Figure 16. Seasonal average directional wave spectrum during different years. The colour bar is for spectral energy $\left(\mathrm{m}^{2}\right.$ degrees $\left.{ }^{-1} \mathrm{~Hz}^{-1}\right)$. The spectral energy is shown in logarithmic scale (base 10).

Directional width denotes the broadness of the directional spectrum with low (high) values for a narrow (board) banded spectrum. The average directional width was less $\left(\sim 15.1^{\circ}\right)$ in 2011 and high $\left(\sim 17.3^{\circ}\right)$ in 2015 (Table 1). During the monsoon period, the single-peaked spectra varied from $56 \%$ (in 2008) to $68 \%$ (in 2011) in different years with a mean value of $60 ; 97 \%$ of the wave spectra were swell dominated (Table 2). As reported earlier (Sanil Kumar and Anjali Nair, 2015), during the monsoon period, the mean wave spectrum was single-peaked since $72 \%$ of the spectral energies were due to swells (Fig. 16). The variations in the contribution of swells in the measured waves inter-annually were less than $5 \%$. During the monsoon period, the spectra, except the waves with frequency $<0.08 \mathrm{~Hz}$, were from 240 to $270^{\circ}$. High-frequency waves from west to northwest (270 to $300^{\circ}$ ) were also observed during July-August. In all the years, reflected swells were also observed in the frequency range $0.07-0.14 \mathrm{~Hz}$ (Fig. 16). In the study area, around $5 \%$ of the incident spectral energy was reflected back during the summer monsoon (Anoop et al., 2014).

\section{Conclusions}

In this study, an analysis of the wave climate in the coastal waters of the eastern Arabian Sea during the summer monsoon has been presented. The work is based on the measured data of waves for 7 years in the nearshore of eastern AS (at $9 \mathrm{~m}$ water depth) from a moored waverider buoy and the reanalysis data covering 37 years. The average significant wave height $\left(H_{\mathrm{m} 0}\right)$ during the monsoon in different years varied from 1.59 to $1.94 \mathrm{~m}$, and there was large variation $(\sim 0.8 \mathrm{~m})$ in the monsoon monthly average $H_{\mathrm{m} 0}$ in different years. The monthly average $H_{\mathrm{m} 0}$ was lowest $(\sim 1.5 \mathrm{~m})$ in June 2009 compared to other years due to the delayed monsoon in 2009. The spectral energy density was predominantly found to be confined to a narrow range $(0.08-0.14 \mathrm{~Hz}$ in frequency and $240-280^{\circ}$ in direction) during the monsoon. The single-peaked spectra varied from 56 to $68 \%$ in different years with an average value of $60 \%$. The average LLJ for the block $0-15^{\circ} \mathrm{N}, 50-75^{\circ} \mathrm{E}$ was found to have a high correlation with the monthly average $H_{\mathrm{m} 0}$ of the eastern AS. The seasonal anomaly of LLJ also follows the pattern of the seasonal anomaly in $H_{\mathrm{m} 0}$. The strong negative seasonal anomaly of $H_{\mathrm{m} 0}$ was observed during the strong El Niño years.

\section{Data availability}

The data on significant wave height and wind speed are from the ERA-Interim global atmospheric reanalysis dataset of the European Centre for Medium-Range Weather Forecasts (ECMWF) and are available at http://www.ecmwf. int/en/research/climate-reanalysis/era-interim. The Oceanic Niño Index can be downloaded from the National Weather Service, National Oceanic and Atmospheric Administration (http://www.cpc.ncep.noaa.gov/products/analysis_ monitoring/ensostuff/ensoyears.shtml). DMI can be downloaded from the following website: http://www.jamstec.go. $\mathrm{jp} / \mathrm{frcgc} / \mathrm{research} / \mathrm{d} 1 / \mathrm{iod} / \mathrm{DATA} / \mathrm{dmi}$.monthly.txt. The measured wave data can be requested from the corresponding author for research work. They are also available in the institute's data repository (http://did.nio.org/users/login/data summary/statistics/sponsored_projects_statistics) (Dee et al., 2011).

Acknowledgements. The Director of National Institute of Oceanography, India, provided support to conduct the study. We thank Jai Singh and Kirti Dubhashi, CSIR-NIO, for the data analysis. This work is a CSIR, New Delhi, funded research programme. We thank the topical editor, Marc Salzmann, and the four reviewers for the critical comments and suggestions, which improved the contents of the paper. This study forms a part of the $\mathrm{PhD}$ work of second author and is NIO contribution no. 5948.

The topical editor, M. Salzmann, thanks H. B. Branger and three anonymous referees for help in evaluating this paper. 


\section{References}

Allan, J. C. and Komar, P. D.: Are ocean wave heights increasing in the eastern North Pacific?, Eos Trans. AGU, 47, 561-567, 2000.

Amrutha, M. M., Sanil Kumar, V., Sharma, S., Singh, J., Gowthaman, R., and Kankara, R. S.: Characteristics of shallow water waves off the central west coast of India before, during and after the onset of the Indian summer monsoon, Ocean Eng., 107, 259-270, doi:10.1016/j.oceaneng.2015.07.061, 2015.

Amrutha, M. M., Sanil Kumar, V., and Singh, J.: Changes in nearshore waves during the active sea/land breeze period off Vengurla, central west coast of India, Ann. Geophys., 34, 215-226, doi:10.5194/angeo-34-215-2016, 2016.

Anoop, T. R., Sanil Kumar, V., and Glejin, J.: A study on reflection pattern of swells from the shoreline of peninsular India, Nat. Hazards, 74, 1863-1879, doi:10.1007/s11069-014-1282-5, 2014.

Anoop, T. R., Sanil Kumar, V., Shanas, P. R., and Johnson, G.: Surface wave climatology and its variability in the North Indian Ocean based on ERA-Interim reanalysis, J. Atmos. Ocean. Tech., 32, 1372-1385, doi:10.1175/JTECH-D-14-00212.1, 2015.

Anoop, T. R., Sanil Kumar, V., Shanas, P. R., Glejin, J., and Amrutha, M. M.: Indian Ocean Dipole modulated wave climate of eastern Arabian Sea, Ocean Sci., 12, 369-378, doi:10.5194/os12-369-2016, 2016.

Chempalayil, P., Sanil Kumar, V., Glejin, J., Udhaba, D. G., and Vinayaraj, P.: Interannual and seasonal variations in nearshore wave characteristics off Honnavar, west coast of India, Curr. Sci., 103, 286-292, 2012.

Chandramohan, P., Nayak, B. U., Sanil Kumar, V., and Pathak, K. C.: Beach processes between Mulgund and Shiroda, west coast of India, Indian J. Mar. Sci., 23, 102-104, 1994.

Cherchi, A. and Navarra, A.: Influence of ENSO and of the Indian Ocean dipole on the Indian summermonsoon variability, Clim. Dynam., 41, 81-103, doi:10.1007/s00382-012-1602-y, 2013.

Datawell B.V.: Datawell Waverider Reference Manual, Datawell BV oceanographic instruments, the Netherlands, 123 pp., 2009.

Dee, D. P., Uppala, S. M., Simmons, A. J., Berrisford, P., Poli, P., Kobayashi, S., Andrae, U., Balmaseda, M. A., Balsamo, G., Bauer, P., Bechtold, P., Beljaars, A. C. M., van de Berg, L., Bidlot, J., Bormann, N., Delsol, C., Dragani, R., Fuentes, M., Geer, A. J., Haimberger, L., Healy, S. B., Hersbach, H., Hólm, E. V., Isaksen, L., Kållberg, P., Köhler, M., Matricardi, M., McNally, A. P., Monge-Sanz, B. M., Morcrette, J.-J., Park, B.-K., Peubey, C., de Rosnay, P., Tavolato, C., Thépaut, J.-N., and Vitart, F.: The ERA-Interim reanalysis: configuration and performance of the data assimilation system: The ERA-Interim reanalysis: Configuration and performance of the data assimilation system, Q. J. Roy. Meteor. Soc., 137, 553-597, 2011.

Espejo, A., Camus, P., Losada, I. J., and Méndez, F. J.: Spectral ocean wave climate variability based on atmospheric circulation patterns, J. Phys. Oceanogr., 44, 2139-2152, 2014.

Findlater, J.: Interhemispheric transport of air in the lowertroposphere over the western Indian Ocean, Q. J. Roy. Meteor. Soc., 95, 400-403, 1969.

Glejin, J., Sanil Kumar, V., Chempalayil, S. P., Singh, J., Pednekar, P., Kumar, K. A., Dora, G. U., and Gowthaman, R.: Variations in swells along eastern Arabian Sea during the summer monsoon, Open J. Mar. Sci., 2, 43-50, 2012.

Glejin, J., Sanil Kumar, V., Balakrishnan Nair, T. M., and Singh, J.: Influence of winds on temporally varying short and long period gravity waves in the near shore regions of the eastern Arabian Sea, Ocean Sci., 9, 343-353, doi:10.5194/os-9-343-2013, 2013.

Goswami, B. N.: South Asian Monsoon, in: Intraseasonal Variability in the Atmosphere-Ocean Climate System, edited by: Lau, W. K. M. and Waliser, D. E., Springer, Berlin, 19-55, 2005.

Goswami, B. N. and Mohan, R. S. A.: Intraseasonal Oscillations and Interannual Variability of the Indian Summer Monsoon, J. Climate, 14, 1180-1198, 2001.

Grinsted, A., Moore, J. C., and Jevrejeva, S.: Application of the cross wavelet transform and wavelet coherence to geophysical time series, Nonlin. Processes Geophys., 11, 561-566, doi:10.5194/npg-11-561-2004, 2004.

Hemer, M. A., Church, J. A., and Hunter, J. R.: Variability and trends in the directional wave climate of the Southern Hemisphere, Int. J. Climatology, 30, 475-491, 2010.

Izaguirre, C., Mendez, F. J., Menendez, M., and Losada, I. J.: Global extreme wave height variability based on satellite data. Geophys. Res. Lett., 38, L10607, doi:10.1029/2011GL047302, 2011.

Joseph, P. V. and Raman, P. L.: Existence of low level westerly jejet stream over the peninsular India during July, Indian J. Meteorol. Geophys., 17, 407-410, 1966.

Joseph, P. V. and Sijikumar, S.: Intraseasonal Variability of the LowLevel Jet Stream of the Asian Summer Monsoon, J. Climate 17, 1449-1458, 2004.

Kuik, A. J., Vledder, G., and Holthuijsen, L. H.: A method for the routine analysis of pitch and roll buoy wave data, J. Phys. Oceanogr., 18, 1020-1034, 1988.

Kulkarni, A., Kripalani, R., Sabade, S., and Rajeevan, M.: Role of intra-seasonal oscillations in modulating Indian summer monsoon rainfall, Clim. Dynam., 36, 1005-1021, doi:10.1007/s00382-010-0973-1, 2011.

Marshall, A. G., Hendon, H. H., Durrant, T. H., and Hemer, M. A.: Madden Julian Oscillation impacts on global ocean surface waves, Ocean Model., 96, 136-147, 2015.

Nayak, R.: Coupling between the North Indian Ocean and Monsoons: A Model Based Study of the Thermal Structure Cycling in the Central Arabian Sea, VDM Verlag Dr. Müller, 148 pp., 2013.

Pierson, W. J. and Moskowitz, L.: A proposed form for fully developed seas based on the similarity theory of S. A. Kitaigorodski, J. Geophys. Res., 69, 5181-5190, 1964.

Portilla, J., Ocampo-Torres, F. J., and Monbaliu, J.: Spectral Partitioning and Identification of Wind Sea and Swell, J. Atmos. Ocean. Tech., 26, 117-122, 2009.

Rajeevan, M., Gadgil, S., and Bhate, J.: Active and break spells of the Indian summer monsoon, J. Earth Syst. Sci., 119, 229-247, 2010.

Raju, P. V. S., Mohanty, U. C., and Bhatla, R.: Onset characteristics of the southwest monsoon over India, Int. J. Climatol., 25, 167$182,2005$.

Reason, C. J. C, Allan, R. J., Lindesay, J. A, and Ansell, T. J.: ENSO and climatic signals across the Indian Ocean Basin in the global context: part I, Interannual composite patterns, Int. J. Climatol., 20 1285-1327, 2000.

Riser, S. C., Nystuen, J., and Rogers, A.: Monsoon effects in the Bay of Bengal inferred from profiling float-based measurements of wind speed and rainfall, Limnol. Oceanogr., 53, 2080-2093, 2008. 
Saji, N. H., Goswami, B. N., Vinayachandran, P. N., and Yamagata, T.: A dipole mode in the tropical Indian Ocean, Nature, 401, 360363, 1999.

Sandeep, S. and Ajayamohan, R.: Poleward shift in Indian summer monsoon low level jetstream under global warming, Clim. Dynam. 45, 337-351, 2015.

Sanil Kumar, V. and Anjali Nair, M.: Inter-annual variations in wave spectral characteristics at a location off the central west coast of India, Ann. Geophys., 33, 15-167, doi:10.5194/angeo-33-1592015, 2015.

Sanil Kumar V. and Anoop, T. R.: Spatial and temporal variations of wave height in shelf seas around India, Nat. Hazards, 78, 16931706, doi:10.1007/s11069-015-1796-5, 2015.

Sanil Kumar, V. and Muhammed Naseef, T.: Performance of ERAInterim wave data in the nearshore waters around India, J. Atmos. Ocean. Tech., 32, 1257-1269, doi.:10.1175/JTECH-D-1400153.1, 2015.

Sanil Kumar, V., Anand, N. M., Ashok Kumar, K., and Mandal, S.: Multipeakedness and groupiness of shallow water waves along Indian coast, J. Coastal Res., 19, 1052-1065, 2003.

Sanil Kumar, V., Johnson, G., Dora, G. U., Chempalayil, S. P., Singh, J., and Pednekar, P.: Variations in nearshore waves along Karnataka, west coast of India, J. Earth Syst. Sci., 121, 393-403, doi:10.1007/s12040-012-0160-3, 2012.

Sanil Kumar, V., Glejin Johnson, K. K., Dubhashi, T. M., and Balakrishnan, N.: Waves off Puducherry, Bay of Bengal, during cyclone THANE, Nat. Hazards, 69, 509-522, doi:10.1007/s11069013-0713-z, 2013.

Sanil Kumar, V., Shanas, P. R., and Dubhashi, K. K.: Shallow water wave spectral characteristics along the eastern Arabian Sea, Nat. Hazards, 70, 377-394, doi:10.1007/s11069-013-0815-7, 2014.

Sasaki, W., Iwasaki, S. I., Matsuura, T., Iizuka, S., and Watabe, L.: Changes in wave climate off Hiratsuka, Japan, as affected by storm activity over the western North Pacific, J. Geophys. Res., 110, C09008, doi:10.1029/2004JC002730, 2005.
Schott, F. A., Xie, S. P., and McCreary, J. P.: Indian Ocean circulation and climate variability, Rev. Geophys., 47, RG1002, doi:10.1029/2007RG000245, 2009.

Shanas, P. R., Sanil Kumar, V., and Hithin, N. K.: Comparison of gridded multi-mission and along track mono-mission satellite altimetry wave heights with in-situ near-shore buoy data, Ocean Eng., 83, 24-35, 2014.

Sikka, D. R.: Some aspects of the large-scale fluctuations of summer monsoon rainfall over India in relations to fluctuations in the planetary and regional scale circulation parameter, J. Earth Syst. Sci., 89, 179-195, 1980.

Sooraj, K. P., Terray, P., and Mujumdar, M.: Global warming and the weakening of the Asian summer Monsoon circulation: assessments from the CMIP5 models, Clim. Dynam. 45, 1-20, 2014.

Stopa, J. E. and Cheung, K. F.: Intercomparison of Wind and Wave Data from the ECMWF Reanalysis Interim and the NCEP Climate Forecast System Reanalysis, Ocean Model., 75, 65-83, 2014.

Walker, J. M., Bordoni, S., and Schneider, T.: Interannual Variability in the Large-Scale Dynamics of the South Asian Summer Monsoon, J. Climate, 28, 3731-3750, 2015.

Webster, P. J., Magaña, V. O., Palmer, T. N., Shukla, J., Tomas, R. A., Yanai, M., and Yasunari, T.: Monsoons: Processes, predictability, and the prospects for prediction, J. Geophys. Res., 103, 14451-14510, doi:10.1029/97JC02719, 1998.

Young, I. R. and Verhagen, L. A.: The growth of fetch limited waves in water of finite depth, Part I: Total energy and peak frequency, Coastal Eng., 29, 47-78, 1996.

Zhang, C.: Madden-Julian Oscillation, Rev. Geophys., 43, 1-36, doi:10.1029/2004RG000158, 2005. 